\title{
1 Evaluating Formation Fluid Models and Calibrations Using Clumped Isotope \\ 2 Paleothermometry on Bahamian Dolomites
}

3 Sean T. Murray ${ }^{*}$ and Peter K. Swart*

4 "Department of Marine Geosciences, Rosenstiel School of Marine and Atmospheric Science,

5 University of Miami, Miami, Florida 33149 USA

6 (Corresponding Author Email: smurray@rsmas.miami.edu, Tel: 1-561-866-4591)

8 Abstract

The use of stable oxygen isotopes to understand the mechanisms of dolomite formation

11 surface conditions. Several studies have attempted to address this problem, either by

12 precipitating high temperatures ordered dolomites and extrapolating the data to low temperatures

13 or by using more disordered very-high $\mathrm{Mg}$-calcites as a proxy for low temperature dolomites.

14 The result is eight equations that disagree significantly from each other (by as much as $\sim 3.6 \%$ in

15 the $\delta^{18} \mathrm{O}$ value of the precipitating fluid at $25^{\circ} \mathrm{C}$ ), and produce differences which can greatly

16 affect the interpretation of the formation mechanisms for low temperature dolomites. However,

17 by combining the recently developed clumped-isotope paleothermometer, an independent

18 isotopic measurement $\left(\Delta_{47}\right)$ that directly relates to the temperature of formation, to Late Miocene

19 to Pleistocene aged dolomites from the Bahamas with a well-constrained thermal and fluid

20 history, we have attempted to narrow down the viable equations used to interpret the $\delta^{18} \mathrm{O}$ values 21 of dolomites.

The clumped-isotope temperatures measured on the Bahamian dolomites $\left(16-37^{\circ} \mathrm{C}\right)$

23 agrees with the range of temperatures expected in the Bahamas. Pairing these temperatures with

24 geological and mineralogical arguments, we favor the equation suggested by Matthews and Katz

25 (1977), as it is the only one that produces realistic $\delta^{18} \mathrm{O}$ fluid values across the range of clumped-

26 isotope temperatures. Both the clumped-isotope temperatures and $\delta^{18} \mathrm{O}$ values of the

27 precipitating fluid show a strong positive covariance that we have interpreted as reflecting the

28 mixing of surface brines that have undergone varying amounts of evaporation and normal

29 seawater. The different mechanisms driving these fluids included formation by normal marine

30 seawater driven by the compensatory flow of the mixing zone, bank wide Kohout convection,

31 and evaporative brine reflux. 


\section{Introduction}

It is well known that massive dolomites commonly replace shallow-water carbonate sediments formed at Earth surface temperatures (Land, 1980, 1998), yet the failure of laboratory studies to reproduce ordered stoichiometric dolomite under similar conditions has limited our ability to understand their formation. . Modern seawater for example is significantly over saturated with respect to dolomite (Arvidson and Mackenzie, 1999), yet the mineral does not readily precipitate from marine waters and most attempts to precipitate dolomite in the laboratory at reasonable sedimentary temperatures have met with failure; the exception being studies in which very high Mg-calcites, sometimes referred to as protodolomites, which lack evidence of cation ordering (Gregg et al., 2015), were formed at temperatures between 25 and $100{ }^{\circ} \mathrm{C}$ (Fritz and Smith, 1970; Vasconcelos and McKenzie, 1997).

Although the $\delta^{18} \mathrm{O}$ value of dolomite $\left(\delta^{18} \mathrm{O}_{\text {dolomite }}\right)$ has been frequently employed to understand dolomite formation, the estimates of equilibrium $\delta^{18} \mathrm{O}$ values for dolomites have varied widely (Land, 1980). Several approaches have been employed to establish the fractionation factor $(\alpha)$ between the $\delta^{18} \mathrm{O}_{\text {dolomite }}$ and the $\delta^{18} \mathrm{O}$ of the precipitating fluid $\left(\delta^{18} \mathrm{O}_{\text {fluid }}\right)$ (equation 1).The fractionation factor varies as a function of temperature and usually has the form as defined in equation 2. In equation 2, variables A and B vary according to the mineral under consideration and $\mathrm{T}$ is temperature in degrees Kelvin $(\mathrm{K})$.

$$
\begin{gathered}
\alpha_{D F}=\frac{\delta^{18} \text { O Dolomite }+1000}{\delta^{18} \text { O Fluid }+1000} \\
1000 \ln \alpha_{\text {Dolomite-Fluid }}=A\left(10^{6} T^{-2}\right)+B
\end{gathered}
$$

New equations defining $\alpha$ are still being proposed with little agreement as to which relationship is correct (Land, 1980, 1983; Horita, 2014). Some of the earliest attempts to determine the $\alpha$ value for dolomites involved examining co-occurring calcites and dolomites

57 (Friedman and Hall, 1963; Degens and Epstein, 1964; Sheppard and Schwarcz, 1970) and were based on the premise that the dolomite and calcite formed at the same time and from the same fluid in isotopic equilibrium. Working under the assumption that the equilibrium relationship

60 between calcite and its parent fluid has been fairly well constrained (Friedman and O'Neil, 1977;

61 Kim and O'Neil, 1997), any oxygen isotopic difference between co-evolved calcite and the

62 dolomite could then be attributed to the equilibrium fractionation value of the dolomite and the 
parent fluid (Land, 1980, 1983; Budd, 1997). While many studies did show a consistent enrichment of the ${ }^{18} \mathrm{O}$ of dolomites compared to calcite by 3 to $6 \%$, this method was hindered by the difficulty in establishing that the calcites and dolomites being studied were cogenetic and the wide range of differences in $\delta^{18} \mathrm{O}$ observed.

Later studies approached the problem by examining the equilibrium isotopic fractionation of well-ordered dolomites precipitated at elevated temperatures (Northrop and Clayton, 1966; O'Neil and Epstein, 1966; Matthews and Katz, 1977; Horita, 2014) and extrapolating these results to lower temperatures. This method proved to be unsatisfactory as the extrapolation to sedimentary temperatures resulted in significant error. Other studies precipitated very-high $\mathrm{Mg}$ calcites or protodolomites at lower temperatures (Fritz and Smith, 1970; Vasconcelos et al., 2005). However, as it is known that $\delta^{18} \mathrm{O}_{\text {dolomite }}$ values are sensitive to both ordering and stoichiometry (Vahrenkamp and Swart, 1994), there is some doubt whether these equations are applicable to well-ordered, more stoichiometric forms of the mineral (Gregg et al., 2015). A final method used a theoretical approach (Zheng, 1999) based on a modified increment method, but it is uncertain if this equation is applicable to naturally occurring dolomite as well (Horita and Clayton, 2007). If all of these various calibrations are considered together, the result is a range in the $\delta^{18} \mathrm{O}_{\text {dolomite }}-\delta^{18} \mathrm{O}_{\text {fluid }}$ fractionation $(\alpha)$ of $\sim 1.0315-1.0351$ for a dolomite precipitated at $25^{\circ} \mathrm{C}$. Assuming the temperature of formation is known, this range is large enough $\left(\sim 3.6 \%\right.$ at $\left.25^{\circ} \mathrm{C}\right)$ to render the $\delta^{18} \mathrm{O}_{\text {fluid }}$ value of little use in distinguishing between the different types of fluids that are reasonable for dolomite formation (Figure 1).

\section{Clumped Isotopes}

The clumped isotope paleothermometer (Ghosh et al., 2006; Huntington et al., 2009) is dependent upon the systematic change in the abundance of carbonate molecules that have multiple substitutions of rare, heavy isotopes in their structure (e.g. ${ }^{13} \mathrm{C}^{18} \mathrm{O}^{16} \mathrm{O}_{2}$ ). A number of studies (Ghosh et al., 2006; Ghosh et al., 2007; Dennis and Schrag, 2010; Eagle et al., 2010; Tripati et al., 2010; Daëron et al., 2011; Thiagarajan et al., 2011; Passey and Henkes, 2012; Saenger et al., 2012; Eagle et al., 2013; Grauel et al., 2013; Henkes et al., 2013; Zaarur et al., 2013; Came et al., 2014; Fernandez et al., 2014; Tang et al., 2014; Wacker et al., 2014; Defliese

91 et al., 2015; Kele et al., 2015; Kluge et al., 2015; Tripati et al., 2015; Bonifacie et al., 2016;

92 Kelson et al., 2016; Winkelstern et al., 2016) have shown a measurable difference in the 93 abundance of these multiply substituted "clumped" isotopologues with changes in temperature 
94 within a variety of organic and inorganic carbonates that have formed at known temperatures.

95 This technique has enabled a new approach to the problems of studying dolomites as the change

96 in abundance of clumped isotopes is strictly controlled by the temperature of the system and is

97 therefore completely independent of the composition of the parent fluid.

98 The measurement of clumped isotopes is based on the mass 47 of $\mathrm{CO}_{2}$, primarily focused 99 on the most abundant multiply substituted species ${ }^{13} \mathrm{C}^{18} \mathrm{O}^{16} \mathrm{O}$, derived from the acid digestion of 100 carbonates. The variable $\Delta_{47}$ (Wang et al., 2004) is used to describe the deviation of mass $47 \mathrm{CO}_{2}$ 101 isotopologues in carbonate samples $\left(\mathrm{R}_{47}\right)$ relative to the same bulk isotopic composition except 102 that it has been stochastically redistributed $\left(\mathrm{R} *{ }_{47}\right)$, .

$$
\Delta_{47}=\left(\frac{R_{47}}{R_{47}^{*}}-1\right) \times 1000
$$

Changes in the $\Delta_{47}$ value are then directly related to temperature through calibrations, with decreasing $\Delta_{47}$ values associated with increasing formation temperatures.

The work described in this paper applies clumped-isotope paleothermometry to dolomites

107 that have formed on secluded Cenozoic aged islands in the Bahamas. While dolomite is

108 commonplace in the ancient, the context of its formation is often difficult to establish as

109 increasing age often positively correlates with increased burial depth, diagenesis,

110 metamorphosis, and exposure to variable environmental settings that all could overprint the 111 original dolomite composition. By examining dolomites that have formed in the more recent

112 past, the variables which have contributed to a dolomites formation can be better constrained.

$113 \quad$ Interpreting $\delta^{18} O_{\text {fluid }}$ values

114 In this study, the calculated clumped-isotope temperatures have been utilized to better 115 constrain how each of the different $\delta^{18} \mathrm{O}_{\text {dolomite }}-\delta^{18} \mathrm{O}_{\text {fluid }}$-temperature calibrations would impact 116 the interpretation of the conditions and formation mechanisms of the Bahamian dolomites. The 117 interpretations are based on a generalized range of $\delta^{18} \mathrm{O}_{\text {fluid }}$ values that could possibly have 118 existed in the Bahamas relative to the modern day environment. The various models of formation 119 have then been evaluated based on the geologic context of the samples and the ability of the 120 different isotopic calibrations to accurately describe the formation of low temperature dolomites.

121 The Bahamas (Figure 2) are composed of series of isolated carbonate platforms that

122 currently receive no fluviatile siliciclastic input and have no known interactions with high 123 temperature hydrothermal or tectonically induced fluids either in the modern or in ancient times 
124 extending back to the late Miocene. The modern day sea-surface temperatures range from $\sim 22$ to

$12530^{\circ} \mathrm{C}$ in the open waters with $\delta^{18} \mathrm{O}_{\text {fluid }}$ compositions ranging from $+0 \%$ o to $+2.5 \%$, averaging

126 around $+1.5 \pm 0.3 \%$ o (Swart et al., 2009). With the exception of glacio-eustatic changes in sea

127 level, there is no geologic evidence to suggest that the environment in the Bahamas has changed

128 significantly since the Miocene.

129 Based on these constraints, three different interpretations of the possible $\delta^{18} \mathrm{O}_{\text {fluid }}$ values

130 of the dolomites have been proposed. The first is over the range of +0.0 to $+2.5 \%$, where the

$131 \delta^{18} \mathrm{O}_{\text {fluid }}$ values are indicative of formation from normal marine seawaters. Dolomites formed

132 from these fluids are thought to have most likely have formed through the flushing process of

133 Kohout convection (Kohout, 1967), in which flow is driven by the inward movement of cold

134 dense fluids surrounding the platform to displace the warmer pore fluids of the platform interior,

135 as it is capable of supplying the large amounts of seawater to the sight of dolomitization over an

136 extended period of time (Figure 3) and has already been attributed to the formation of some

137 dolomites in this study (Caspard et al., 2004). Other models of fluid flows that could have

138 contributed to dolomitization by normal seawater are well discussed in Budd (1997). The second

139 interpretation is for when the calculated $\delta^{18} \mathrm{O}_{\text {fluid }}$ values fall below the range for normal seawater

$140(<0 \%$ ) where it is assumed that the parent fluid would have a significant incorporation of fresh

141 water, which typically has a $\delta^{18} \mathrm{O}_{\text {fluid }}$ value less than $0 \%$, and would therefore be described as a

142 mixed fluid most likely formed in the mixing zone, a chemical layer where seawater and fresh

143 water intermix. Associated with the mixing zone is a compensatory fluid flow of normal

144 seawater that has also been suggested to be a driver behind dolomitization associated with the

145 mixing zone (Vahrenkamp and Swart, 1994; Budd, 1997), however dolomites formed from this

146 flow would have a $\delta^{18} \mathrm{O}_{\text {fluid }}$ value similar to normal seawater $(+0$ to $+2.5 \%$ ) while dolomites

147 formed within the chemical mixing zone or within the freshwater lens would have lower $\delta^{18} \mathrm{O}_{\text {fluid }}$

148 values indicative of a mixture between normal seawater and freshwater. There are, however,

149 significant arguments which will be discussed later to suggest that dolomite cannot form within

150 the chemical mixing zone or from fresh water. In cases where the $\delta^{18} \mathrm{O}_{\text {fluid }}$ values are greater than

$151 \sim+2.5 \%$, these fluids are interpreted to have been produced by the process of evaporation of

152 normal marine seawater and are therefore described as evaporative fluids. 


\section{Samples}

Several studies have identified extensive dolomitization throughout the Bahamian platform from the Cretaceous to the Modern in the form of both well-ordered stoichiometric dolomites and less ordered calcian dolomites (Goodell and Garman, 1969; Supko, 1977; Beach

158 and Ginsburg, 1980; Kaldi and Gidman, 1982; Pierson, 1983; Williams, 1985; Dawans and

159 Swart, 1988; Vahrenkamp, 1988; Vahrenkamp and Swart, 1994; Swart and Melim, 2000;

160 Winkelstern and Lohmann, 2016). The samples in this study have been taken from cores

161 collected on San Salvador, Little Bahama Bank (LBB), and Great Bahama Bank (GBB) (Figure $1624)$

\section{$\underline{\text { San Salvador }}$}

164 The $\sim 168$ m core was drilled in the late 1960's and has been the focus of multiple studies 165 (Supko, 1970, 1977; Swart et al., 1987; Dawans and Swart, 1988; McNeill et al., 1988;

166 Vahrenkamp et al., 1991). The core penetrated Pleistocene to Miocene aged carbonates as 167 determined through biostratigraphy (Supko, 1970, 1977), Sr-isotopes (Swart et al., 1987) and 168 magnetostratigraphy (McNeill et al., 1988). A series of dolomitization events, identified using 169 Sr-isotopes and the uranium disequilibrium series dating (Swart et al., 1987; Vahrenkamp et al., 170 1991), suggested the low-Mg calcite (LMC) was diagenetically altered to dolomite during two to 171 five different dolomitization periods between the early Miocene and the Modern (to as recently 172 as <150 ka BP). Six exposure surfaces have been identified within the Pliocene aged interval, 173 each capped with a hard crystalline mimetic, calcian dolomite which displays dolomite ordering 174 but has more $\mathrm{Ca}$ than a stoichiometric dolomite (Dawans and Swart, 1988). The crystalline 175 mimetic dolomite gradually transitions into a more friable microsucrosic, fabric destructive, dolomite which is stoichiometric and well-ordered in a series of alternations (Dawans and Swart,

177 1988). These crystalline mimetic dolomites replace coarse grained, shallow water sediments

178 while the microsucrosic dolomites replace wackestones and mudstones. These cycles may have 179 formed in response to small amplitude (a few meters) Pliocene sea-level cycles (Dawans and 180 Swart, 1988). Between these two textural end members, there is often a transitional texture, 181 termed crystalline microsucrosic, which is comprised of features characteristic of both crystalline 182 mimetic and microsucrosic textures. Also present in the Miocene section of the core is a 183 dolomite termed crystalline non-mimetic that is completely fabric destructive due to the 184 formation of large anhedral to euhedral dolomite crystals. In total, 37 dolomite samples between 
$37 \mathrm{~m}$ and $134 \mathrm{~m}$ depth were collected for this study along with a single LMC sample from 158.5

186 m depth (Figure 4).

$187 \quad$ Little Bahama Bank

188 Two cores were studied from LBB, Walkers Cay (WC1) and Grand Bahama Island

189 (GB2) (Williams, 1985) (Figure 2). The cores are of Middle Miocene to Pleistocene age

190 (McNeill, 1989), with three distinct periods of dolomitization indicated by Sr isotopes in the Late

191 Miocene, Late Pliocene, and Early Pleistocene (Vahrenkamp, 1988; Vahrenkamp et al., 1991).

192 The carbon and oxygen isotopes in the upper portion of both cores show a distinct shift from

193 positive to negative values over $\sim 5 \mathrm{~m}$ (Vahrenkamp and Swart, 1994) (Figure 5). This shift

194 corresponds to a sharp boundary between sediment compositions of pure LMC to pure dolomite

195 at $\sim 52 \mathrm{~m}$. Despite fluctuations in sea level across the Bahamas during the Pleistocene (Hearty and

196 Kindler, 1995), there is no carbon or oxygen isotopic evidence in these cores to suggest that the

197 transition from LMC to dolomite occurred due to falling sea level exposing the sediments to

198 meteoric fluids. Similar to San Salvador, the dolomites in these cores transition from crystalline

199 mimetic to microsucrosic textures associated with sea-level cycles indicated by the presence of

200 non-depositional surfaces.

201 Twelve samples were analyzed from WC1 between 52.1 and $92 \mathrm{~m}$ depth. All of these

202 were $100 \%$ dolomite except for the sample at $52.1 \mathrm{~m}$ which was pure LMC and samples at 59.1

$203 \mathrm{~m}, 61.0 \mathrm{~m}$, and $64.6 \mathrm{~m}$ which were between $76 \%$ and $90 \%$ dolomite, with the remnant portion

204 being LMC. Eleven samples were collected from GB2 between $48.2 \mathrm{~m}$ and $89.9 \mathrm{~m}$ depth, all of

205 which were $100 \%$ dolomite.

206 Great Bahama Bank

207 The Unda core was drilled on the GBB (Figure 2). The sediments in Unda are composed

208 mostly of reefal deposits and platform derived sediments with some deeper marginal deposits

209 towards the bottom of the core (Swart and Melim, 2000; Kenter et al., 2001). While dolomite is

210 found in minor quantities above $108 \mathrm{~m}$, from 292-360 m, just below the Miocene-Pliocene

211 boundary, platform to middle-reef sediments are nearly fully dolomitized. The reef in this section

212 has been interpreted based on faunal assemblages (Budd and Manfrino, 2001) to have formed in

213 relatively deep water (20 to $40 \mathrm{~m}$ ), implying that formation temperatures should be lower than

214 those in the other cores. The reef section is capped by a subaerial exposure horizon which is also

215 a phosphatic marine hardground (Melim et al., 2001). The dolomites in this reefal section 
216 predominately have a crystalline mimetic texture with some intercalated microsucrosic dolomite.

217 In total, 12 samples were taken from the completely dolomitized reefal section of Unda between

218292 and $332 \mathrm{~m}$ depth. Each sample was analyzed for composition using X-ray diffraction and the

219 majority contained $100 \%$ dolomite, with less than 1\% LMC present in samples collected at the

220 depth of $301.75 \mathrm{~m}$ and $311.45 \mathrm{~m}$ and 3\% aragonite found in the sample from depth $302.79 \mathrm{~m}$.

\section{Age of Dolomitization from Sr-isotopes}

The timing of dolomitization in these cores has been constrained using ${ }^{87} \mathrm{Sr} /{ }^{86} \mathrm{Sr}$ ratios

223 (Swart et al., 1987; Vahrenkamp, 1988; Vahrenkamp and Swart, 1990; Vahrenkamp et al., 1991;

224 Swart et al., 2001). Throughout the Neogene, the ${ }^{87} \mathrm{Sr} /{ }^{86} \mathrm{Sr}$ ratio of seawater has been steadily

225 increasing (Burke et al., 1982; DePaolo, 1986). If it is assumed that the only sources of strontium

226 contributing to the dolomites has been derived from the (i) seawater at the time of dolomitization

227 and (ii) the precursor carbonate, it is possible to compare the ${ }^{87} \mathrm{Sr} /{ }^{86} \mathrm{Sr}$ ratio measured in the

228 dolomite samples with the marine Sr-isotope curve of DePaolo (1986). The age from this curve

229 would reflect the oldest possible age of dolomite formation as well as the youngest possible age

230 of the original sediments (Saller, 1984; Swart et al., 1987; Vahrenkamp et al., 1991). This

231 method works under the assumption that the $\mathrm{Sr}$ isotope value of the dolomite is reflective of the

232 last set of fluids the dolomite came into equilibrium with and that the precipitating fluid had the

233 same Sr-isotope composition of seawater at that time. The Bahamas, being an isolated carbonate

234 platform, is sheltered from the common contaminants of strontium, including underlying basalts,

235 aluminosilicates, and the comingling of dramatically different aged sediments making the

236 location ideal for the use of this technique.

237 San Salvador: The ${ }^{87} \mathrm{Sr} /{ }^{86} \mathrm{Sr}$ ratio throughout the core showed an increasing trend from 0.70851

238 at the bottom of the core to 0.70912 at the Plio-Pleistocene boundary. The ${ }^{87} \mathrm{Sr} /{ }^{86} \mathrm{Sr}$ values

239 generally agree with the corresponding value of seawater at the time of deposition (Swart et al.,

240 1987). Some deviation from the increasing trend is found between $53 \mathrm{~m}$ and $79 \mathrm{~m}$, which

241 stratigraphically were dated to have formed at some point during the Pliocene, but are as

242 radiogenic as modern seawater, 0.70923 (DePaolo, 1986). These values suggest dolomitization

243 in this interval occurred less than 500,000 ka BP. The timing of dolomitization was further

244 constrained using ${ }^{234} \mathrm{U}^{230} \mathrm{Th}$ ratios to less than 150,000 ka BP Assuming that dolomitization

245 could not have taken place when the sediments were exposed to meteoric fluids due to the lack

246 of supplied $\mathrm{Mg}$ and an undersaturation with respect to dolomite, this age places the timing of 
247 dolomite formation to periods when sea level was as high as it is in the Modern, such as during 248 marine isotope stage 5e, or during other sea level changes associated with the current high stand.

249 Little Bahama Bank: Dolomitization on LBB was proposed to have taken place in three distinct 250 phases (Vahrenkamp et al., 1991). The first phase was shown to have occurred between 11.5 and $2518.3 \mathrm{Ma}$ (0.70893 to 0.70894 ) to sediments originally deposited in the Middle to Late Miocene.

252 This was followed by a second major phase of dolomitization at the end of the Pliocene, between 2532.8 and 2.2 $\mathrm{Ma}(0.70899$ to 0.70809$)$. A third minor phase was shown to have occurred shortly 254 after the second phase, separated by a non-diagenetically altered limestone layer on top of the 255 phase II dolomites. This unit is dated between the Latest Pliocene and Early Pleistocene 256 (0.70912).

257 Unda: The ${ }^{87} \mathrm{Sr} /{ }^{86} \mathrm{Sr}$ ratio of bulk samples in Unda suggest ages that are similar to the 258 chronostratigraphic ages determined by magnetostratigraphy and biostratigraphy (McNeill et al., 259 2001) which extend from the late Miocene through the Pleistocene. This agreement suggests that 260 diagenesis occurred shortly after deposition. Dolomites that have been isolated from the core 261 have ${ }^{87} \mathrm{Sr} /{ }^{86} \mathrm{Sr}$ ratios that are slightly more radiogenic than the carbonates believed that are 262 believed to be original suggesting dolomitization occurred shortly after deposition (Swart et al., 263 2001).

Methods

Whole rock samples were powdered using a Spex SamplePrep Mixer/Mill 8000 or mortar and pestle. Each sample consisted of $8.0 \pm 0.2 \mathrm{mg}$ of powder weighed into two K1250A 3.71 $\mathrm{mm}$ diameter gas checks plain copper-boats in $4.0 \pm 0.1 \mathrm{mg}$ amounts. Sample digestion methods followed the routine established in Murray et al. (2016) for $90{ }^{\circ} \mathrm{C}$ reactions in a common acid bath $(\mathrm{CAB})$. Copper boats were loaded into a vacuum chamber carousel resting above a CAB

$272105 \%$ phosphoric acid $\left(\mathrm{H}_{3} \mathrm{PO}_{4}\right)$ and attached to the carousel and the entire system was pumped 273 down from atmosphere to a pressure similar to the vapor pressure of phosphoric acid $\left(2 \times 10^{-6}\right.$ 274 mbars). At most four 2-boat samples are run on a single aliquot of acid before the acid was 275 replaced. One run typically consisted of one carbonate standard (Carrara marble) followed by 276 three samples. 
Once dropped in the acid, the sample boats were stirred by a Pyrex ${ }^{\mathrm{TM}}$ coated stirrer bar, and were typically reacted between 45 and 60 minutes, as determined by the complete cessation of bubbles visible in the phosphoric acid. The produced $\mathrm{CO}_{2}$ gas was removed and isolated using a series of U-traps with liquid nitrogen and $-90^{\circ} \mathrm{C}$ methanol. The gas was then passed through a Porapak $^{\mathrm{TM}}$ Type Q 50-80 mesh U-trap maintained at a temperature of -20 to $-30{ }^{\circ} \mathrm{C}$ using a methanol slush. Cleaned samples were removed from the processing line using a $25 \mathrm{ml}$ pearshaped glass vessel with an Ace Glass valve and transferred to a dual-inlet Thermo MAT 253 mass spectrometer. Samples were analyzed at a signal intensity of $12 \mathrm{~V}$ on mass-44 against an in house working gas (WG) that has been cryogenically purified. Analysis took place over multiple intervals between 2012 and 2015. The procedures varied over this time period, being modified to take advantage of advances in the field. Prior to August, 2014, samples were measured over ten acquisitions of 6 on-peak sample-standard measurements (click-clacks). After August 2014, the pressure-baseline (PBL) correction, as described in He et al. (2012), was implemented to manually account for the negative voltages present on the peaks on masses 47 to 49 when high amounts of $\mathrm{CO}_{2}$ were being analyzed. Using the PBL, samples were measured over six acquisitions of 15 on-peak click-clacks which were preceded and succeeded by 5 off-peak clickclacks measuring the PBL. Masses 44 to 49 were then corrected for the PBL by retroactively adding the measured amount back onto peak voltages during post processing.

Although no statistically significant differences (Mann-Whitney, 2-tail, $p=0.77$ ) were found between the $\Delta_{47}$ values calculated using the methods prior or post to August, 2014 (Murray et al., 2016), the main benefit of the PBL correction was improved precision. In addition, many samples run prior to August 2014 were measured subsequently using the PBL and the two sets of results are in agreement.

The $\delta^{13} \mathrm{C}$ and $\delta^{18} \mathrm{O}$ values were simultaneously generated during the measurement of clumped isotopes by measuring masses 45/44 and 46/44 and correcting for the typical isobaric interferences using methods based on Craig (1957) and modified for a multi-collector mass spectrometer as described in Gonfiantini et al. (1993). The $\delta^{13} \mathrm{C}$ and $\delta^{18} \mathrm{O}$ values of the samples

305 differential fractionation of $\mathrm{CO}_{2}$ produced from dolomite relative to calcite during dissolution in phosphoric acid at $90^{\circ} \mathrm{C}$, a constant correction of $-0.8 \%$ was applied to the $\delta^{18} \mathrm{O}$ values of dolomite samples (Sharma and Clayton, 1965; Land, 1980; Vahrenkamp and Swart, 1994). The 
$308 \delta^{13} \mathrm{C}$ and $\delta^{18} \mathrm{O}$ values average standard deviation from replicated samples is $0.03 \%$ and $0.1 \%$ o 309 respectively.

310 In February of 2015, the working gas on the mass spectrometer was changed (from WG1

311 to WG2). The working gases had different $\delta^{13} \mathrm{C}$ and $\delta^{18} \mathrm{O}$ values as determined by measurement 312 against NBS-19 and reported relative to Vienna Pee Dee Belemnite (V-PDB) (WG1: $\delta^{13} \mathrm{C}=$ -

$3132.7 \%$ o $\delta^{18} \mathrm{O}=-6.4 \%$, WG2: $\delta^{13} \mathrm{C}=-9.8 \%$ o $\delta^{18} \mathrm{O}=-7.4 \%$ ).

314 Data reduction and normalization for the calculation of the raw $\Delta_{47}$ value $\left(\Delta_{47-\text { raw }}\right)$, which

315 is the $\Delta_{47}$ of the sample relative to the working gas, followed the methods of Huntington et al.

316 (2009), except for the ${ }^{17} \mathrm{O}$ correction which was based on Craig (1957) and followed the

317 recommendations made in Gonfiantini et al. (1993). Final $\Delta_{47}$ values $\left(\Delta_{47}\right.$-processed $)$ were calculated

318 from the $\Delta_{47 \text {-raw }}$ values using the procedures and standardization methods described Dennis et al.

319 (2011) to place the $\Delta_{47 \text {-raw }}$ values into the carbon dioxide equilibrium scale. This is done by using

320 a collection of standardized $\mathrm{CO}_{2}$ gases that have been either driven to a stochastic distribution by

321 heating to $1000^{\circ} \mathrm{C}$ for several hours in a muffle furnace (heated gases) or by equilibration with

322 one of our internal laboratory water samples in a temperature controlled water bath at either $25^{\circ} \mathrm{C}$

323 or $50^{\circ} \mathrm{C}$ over a period of days. The methods by which these gases are produced and measured can

324 be found in Murray et al. (2016). These standardized $\mathrm{CO}_{2}$ gases are then used to produce a

325 reference framework which accounts for scrambling, compositional nonlinearity, and the non-

326 stochastic nature of the WG by relating the measured $\Delta_{47}$ of the standard gases to their modeled

327 expected values as determined in Wang et al. (2004). All measured data for heated and water-

328 equilibrated standard gases used to calculate $\Delta_{47}$ values in this study can be found in the

329 supplementary materials.

330 An acid digestion temperature fractionation factor was applied to the $\Delta_{47 \text {-processed }}$ value for

331 all samples relative to their bulk mineralogy as determined by X-ray diffraction performed on a

332 Panalytical X-pert Pro and standardized against mixed sediments with a known bulk

333 composition. The $\Delta_{47}$ fractionation factor applied for dolomite was $0.153 \%$ (Murray et al., 2016)

334 and $0.092 \%$ for calcite (Henkes et al., 2013) with any samples composed of a mixed

335 composition being corrected based on a linear interpolation between the two end member

336 fractionations. This method could underestimate the true value based on the non-linearity of $\Delta_{47}$

337 values with respect to end-member mixing of $\mathrm{CO}_{2}$ gases (Defliese and Lohmann, 2015), 
338 however the difference in isotopic values $\left(\delta^{13} \mathrm{C}\right.$ and $\left.\delta^{18} \mathrm{O}\right)$ between the end members is small 339 enough to make this effect negligible.

Recent work has found that the methods used to correct for the abundance of ${ }^{17} \mathrm{O}$ present in $\mathrm{CO}_{2}$ molecules at masses 45 and 46 can have a significant impact (up to $0.1 \%$ ) on the $\Delta_{47 \text { - }}$ processed value of samples if their $\delta^{13} \mathrm{C}$ value is substantially different than the $\delta^{13} \mathrm{C}$ value of the

343 WG (Daëron et al., 2016; Schauer et al., 2016). Both Daëron et al. (2016) and Schauer et al.

344 (2016) compared the impacts of the ${ }^{17} \mathrm{O}$ corrections described in Santrock et al. (1985) relative to 345 the more recent Brand et al. (2010) correction, and both recommended that the correction scheme 346 of Brand et al. (2010) be used in laboratories moving forward. Our laboratory previously used an 347 alternative ${ }^{17} \mathrm{O}$ correction scheme based on the work of Craig (1957) and described by 348 Gonfiantini et al. (1993)

349 All of the data from cores San Salvador, GB2, WC1, and Unda presented in this work 350 have been reevaluated using the recommended Brand et al. (2010) correction. The effect of this 351 change on the $\Delta_{47-\text { raw }}$ value is minimal, typically in the third decimal place and similar or less 352 than the analytical error on the measurement. Looking at the processed $\Delta_{47}$ value ( $\Delta_{47 \text {-processed }}$ ), an

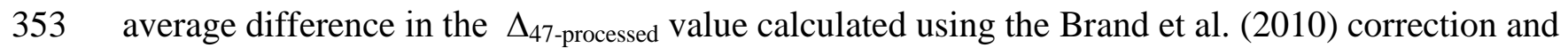
354 those calculated using the Craig (1957) correction, is $0.021 \pm 0.008 \%$. This difference is slightly

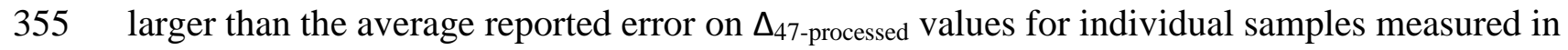
356 this study ( $\sim 0.013 \%$ ), and can be translated to an average decrease on reported temperatures of $357 \sim 3$ to $5^{\circ} \mathrm{C}$. The reason the difference is larger in the $\Delta_{47 \text {-processed }}$ value relative to the $\Delta_{47 \text {-raw value }}$ 358 is the compounding influence of the small changes calculated in $\Delta_{47 \text {-raw }}$ values for heated and

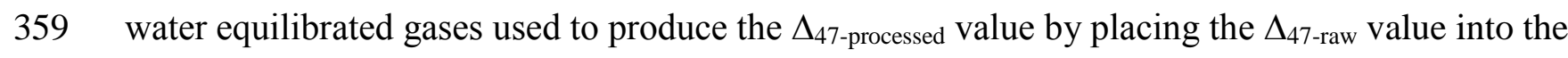
360 Dennis et al. (2011) reference frame. Further interpretation of the effects of this change on the 361 data presented in this study can be found in the supplementary material, but it is currently 362 considered that the differences attributed to the different ${ }^{17} \mathrm{O}$ corrections are inconsequential to 363 the conclusions presented in the rest of this work. We also reanalyzed some of the dolomite acid 364 digestion temperature fractionation work presented in Murray et al. (2016) and found that the 365 differing ${ }^{17} \mathrm{O}$ corrections have no impact on the reported fractionation measured in that study. 366 These data and further discussion are presented in the supplementary material; however, the rest 367 of this work is presented in its original form using the modified Craig (1957) correction. 
Temperatures were calculated for both dolomite and calcite using the calibration of

369 Ghosh et al. (2006) in the absolute reference frame of Dennis et al. (2011). Recently published 370 dolomite specific calibrations (Bonifacie et al., 2016; Winkelstern et al., 2016) produce similar 371 temperatures to those calculated using the Ghosh et al. (2006) within the temperature range of 372 the samples being reported, but we continue using the Ghosh calibration as it is most similar to 373 our own internally measured calibration on manually precipitated calcites using the Brand et al. 374 (2010) correction $\left(\delta^{13} \mathrm{C}:-9.96\right.$ to $+0.30 ; \delta^{18} \mathrm{O}:-13.66$ to +1.50$)$ over a larger range of 375 temperatures and no significant difference has been found between calcite and dolomite 376 calibrations. In order to check for contamination, samples were scrutinized based on their offset 377 of $\delta^{48}$ and $\Delta_{48}$ from that of standardized gases (Huntington et al., 2009) and to replicates of itself 378 Any sample that exceeded one standard deviation of the average values was removed from 379 further analysis, but the data is still presented in the supplementary materials.

380 In order to check for long term stability in measurements, a Carrara marble sample was 381 measured daily producing an average processed $\Delta_{47}$ value ( $\pm 1 \sigma$ standard deviation) during the 382 time frame of running these samples was $0.392 \pm 0.029 \%(n=443)$ which is comparable to the 383 reported average value from four different laboratories of $0.395 \pm 0.008 \%$ (Dennis et al., 2011) 384 despite being a different samples of Carrara marble. Since 2014, four other standards (ETH 1 to 385 4), distributed to clumped-isotope laboratories by Eidgenössische Technische Hochschule 386 (ETH), Zürich, have also been measured. The average measured values $( \pm 1 \sigma)$ were $0.278 \pm$ $0.017 \%$ o $(n=7), 0.295 \pm 0.017 \%$ o $(n=5), 0.698 \pm 0.016 \%$ o $(n=5)$, and $0.565 \pm 0.014 \%$ o $(n=7)$

388 for standards ETH 1, 2, 3, and 4 respectively. Our values for ETH 1 and 3 are within one 389 standard deviation of the reported values in Meckler et al. (2014), but 2 and 4 exceed their value 390 by $\sim 0.035 \%$. However, that study does not report standard deviations of their accepted $\Delta_{47}$ 391 values for the ETH standards making it difficult to compare.

392 The parent fluid values for dolomites were calculated using the published calibrations of 393 O'Neil and Epstein (1966), Northrop and Clayton (1966), Fritz and Smith (1970), Sheppard and 394 Schwarcz (1970), Matthews and Katz (1977), Vasconcelos et al. (2005), and Horita (2014). The 395 calibrations used in this study for O'Neil and Epstein (1966), Northrop and Clayton (1966), Fritz 396 and Smith (1970), and Sheppard and Schwarcz (1970) were originally published in Land (1983), 397 based on the measured data from the respective studies and the formulas calculated assuming a 
fluid composition of $0 \%$. The composition of the parent fluid for calcite samples was calculated

399 from the calibration of Kim and O'Neil (1997).

\section{Results}

A summary of the stable and clumped-isotope results are presented in Table 1. All $\Delta_{47}$ values presented in the rest of this work are the $\Delta_{47 \text {-processed }}$ values in the carbon dioxide equilibrium scale. Errors on both temperatures and $\Delta_{47}$ values are $\pm 1 \sigma$ of the replicates.

\section{$405 \quad$ San Salvador}

The $\delta^{18} \mathrm{O}_{\text {dolomite }}$ values range from +1.2 to $+2.9 \%$, with a general trend of lower values in 407 the upper $10 \mathrm{~m}$ and bottom $70 \mathrm{~m}$ of the dolomitized section. The $\delta^{13} \mathrm{C}_{\text {dolomite }}$ values have a 408 slightly decreasing trend up core with values ranging from +2.9 to $+1.5 \%$. The calcite sample 409 from the bottom of the core has isotopic values of -1.3 and $-2.1 \%$ for $\delta^{18} \mathrm{O}$ and $\delta^{13} \mathrm{C}$ respectively. 410 The $\Delta_{47}$ values of the dolomites varied between $0.657 \pm 0.007 \%$ and $0.738 \pm 0.003 \%$. The 411 calcite sample had an average $\Delta_{47}$ value of $0.689 \pm 0.003 \%$. This would suggest a range of 412 formation temperatures for the dolomites between $19 \pm 1$ to $37 \pm 2{ }^{\circ} \mathrm{C}$, and $29 \pm 1{ }^{\circ} \mathrm{C}$ for the 413 calcite.

\section{Little Bahama Bank}

415 The LBB dolomites have more positive $\delta^{18} \mathrm{O}$ values than those from San Salvador 416 ranging from +2.8 to $+3.9 \%$. The $\delta^{13} \mathrm{C}$ values $(+1.3$ to $+2.8 \%$ ) are similar to those in San 417 Salvador. The pure calcite from the top of $\mathrm{WC} 1$ has $\delta^{18} \mathrm{O}$ and $\delta^{13} \mathrm{C}$ values of $-2.1 \%$ and $-0.3 \%$, 418 respectively. The mixed carbonate samples from the upper part of WC1 have more negative $\delta^{18} \mathrm{O}$ 419 values than the pure dolomites in the core, most likely due to the presence of small amounts of 420 calcite. The $\Delta_{47}$ values of the GB2 dolomites ranged from $0.720 \%$ o to $0.762 \%$. This range 421 produced an average calculated temperature of $20 \pm 3^{\circ} \mathrm{C}$. The $\mathrm{WC} 1$ core had $\Delta_{47}$ values between $4220.712 \%$ and $0.752 \%$, equating to an average temperature of $20 \pm 3^{\circ} \mathrm{C}$. The LMC sample 423 produced an average temperature of $32 \pm 3^{\circ} \mathrm{C}$ and the three mixed dolomite/LMC samples had 424 temperatures ranging from 16 to $26^{\circ} \mathrm{C}$ using linear interpolation between the calcite and dolomite 425 acid fractionation factors. 
The dolomitized section of the Unda core shows minimal changes in $\delta^{18} \mathrm{O}_{\text {dolomite }}$ values,

428 varying from +2.2 to $+3.2 \%$, with a slight increasing trend, while the $\delta^{13} \mathrm{C}$ values only range by

$4290.4 \%$ o from +2.6 to $+3.0 \%$. The Unda dolomites yielded $\Delta_{47}$ values ranging between 0.740 and

$430 \quad 0.758 \%$. This is equivalent to a temperature range of 16 to $19{ }^{\circ} \mathrm{C}$.

\section{Discussion}

433 The dolomites found in Cenozoic aged Bahamian sediments offer an opportunity to

434 understand the process of dolomitization because they are young in age, have never been buried

435 to significant depths, or subjected to elevated temperatures. Despite the fact that the dolomitizing

436 fluids are likely to be derivatives of normal seawater (see below), there are still a number of

437 possible fluid compositions and mechanisms that must be considered. These include

438 dolomitization from mixing-zone derived fluids, normal seawater, and evaporated fluids. Hence,

439 knowledge of the temperature of formation, as derived from the clumped-isotope data, enables

440 the values of the $\delta^{18} \mathrm{O}_{\text {fluid }}$ to be determined and consequently help constrain the mechanisms and

441 solutions involved.

Isotopic Composition of the Fluids

444 Each of the eight equations proposed to link temperature to the fractionation between the

$445 \quad \delta^{18} \mathrm{O}_{\text {dolomite }}$ and $\delta^{18} \mathrm{O}_{\text {fluid }}$ values (Northrop and Clayton, 1966; O'Neil and Epstein, 1966; Fritz and

446 Smith, 1970; Sheppard and Schwarcz, 1970; Matthews and Katz, 1977; Zheng, 1999;

447 Vasconcelos et al., 2005; Horita, 2014) can be used to generate $\delta^{18} \mathrm{O}_{\text {fluid }}$ values using the

$448 \quad \delta^{18} \mathrm{O}_{\text {dolomite }}$ and temperatures calculated from clumped isotopes (Figure 6). All of these equations

449 produce a similar co-varying trend between temperature and $\delta^{18} \mathrm{O}_{\text {fluid }}$ values. There are no clear

450 trends between the $\delta^{18} \mathrm{O}_{\text {dolomite }}$ and $\delta^{18} \mathrm{O}_{\text {fluid }}$ values or between the $\delta^{18} \mathrm{O}_{\text {dolomite }}$ values and

451 temperature. There may be a slight trend of decreasing $\delta^{18} \mathrm{O}_{\text {dolomite }}$ values and increasing

452 temperature visible in San Salvador, WC1, and GB2, but core Unda has little variation in the

$453 \delta^{18} \mathrm{O}_{\text {dolomite }}$ value and that trend is not apparent (Figure 7). This would suggest that the

454 composition of the fluid covaries with its temperature and that these two variables are balanced

455 in such a way as to have little impact on the $\delta^{18} \mathrm{O}_{\text {dolomite }}$ value. However, the errors on clumped

456 isotope temperatures (average error of $3 \pm 2^{\circ} \mathrm{C}$ ), as well as the $\delta^{18} \mathrm{O}_{\text {fluid }}$ values calculated using 
457 those temperatures (average error of $0.8 \pm 0.5 \%$, though this reported error does not take into 458 account the error on temperature measurements), are large enough that they could be masking 459 trends with the $\delta^{18} \mathrm{O}_{\text {dolomite }}$ and what is seen is simply an artifact. If the trend is real, then in the 460 three-part system of the variables $\delta^{18} \mathrm{O}_{\text {dolomite, }} \delta^{18} \mathrm{O}_{\text {fluid, }}$ and temperature, the mechanism most 461 likely to control the $\delta^{18} \mathrm{O}_{\text {fluid }}$ value during periods of increased temperature is evaporation. Based 462 on the large range of fluid compositions calculated for the Bahamian dolomites, there would 463 have to have been multiple fluids that have undergone different amounts of evaporation that have 464 contributed to the bulk dolomitization of the Bahamas.

465 When comparing the mean $\delta^{18} \mathrm{O}_{\text {fluid }}$ value $( \pm 1 \sigma)$ for all the samples determined using each 466 equation, the most negative average $\delta^{18} \mathrm{O}_{\text {fluid }}$ values are calculated using the equations of 467 Northrop and Clayton (1966) (-1.53 $\pm 1.09 \%$ ) and O'Neil and Epstein (1966) (-1.26 $\pm 1.10 \%$ ) 468 and the most positive average $\delta^{18} \mathrm{O}_{\text {fluid }}$ values are calculated using the equations of Matthews and 469 Katz (1977) $(+1.73 \pm 0.90 \%$ ) and Vasconcelos et al. (2005) $(+1.99 \pm 0.80 \%$ ) relationships. The $470 \sim 3.6 \%$ range in $\delta^{18} \mathrm{O}_{\text {fluid }}$ values predicted from a single $\delta^{18} \mathrm{O}_{\text {dolomite }}$ value at a specific temperature 471 from these eight different equations can therefore suggest formation of these dolomites by fluids 472 comprised anywhere from fresh water mixed with normal seawater $\left(\delta^{18} \mathrm{O}_{\text {fluid }}<0 \%\right.$ ) to 473 evaporative brines $\left(\delta^{18} \mathrm{O}_{\text {fluid }}>2.5 \%\right.$ ). In order to determine which relationship is the most 474 applicable to the Bahamas, it is necessary to critically evaluate all of the equations and ascertain 475 which produces $\delta^{18} \mathrm{O}_{\text {fluid }}$ values that are consistent with the various models of dolomitization 476 proposed for the Bahamas.

477 The various equations have been separated into three groups based on the $\delta^{18} \mathrm{O}_{\text {fluid }}$ values 478 calculated using the samples analyzed in this study. First, there are the equations which produce 479 predominantly negative $\delta^{18} \mathrm{O}_{\text {fluid }}$ values (range of $\delta^{18} \mathrm{O}_{\text {fluid }}$ values from -3.0 to $+2.0 \%$ ) (Northrop 480 and Clayton, 1966; O'Neil and Epstein, 1966; Sheppard and Schwarcz, 1970) Second, are the 481 equations that produce mostly positive values (range of $\delta^{18} \mathrm{O}_{\text {fluid }}$ values from -1.0 to $+3.5 \%$ 482 (Zheng, 1999; Horita, 2014).Finally, there are the equations that produce values which are 483 exclusively positive (range of $\delta^{18} \mathrm{O}_{\text {fluid }}$ values from 0.0 to $+4 \%$ ) (Fritz and Smith, 1970; 484 Matthews and Katz, 1977; Vasconcelos et al., 2005) (Figure 6). 
Assuming that the first group of equations which produce predominately negative $\delta^{18} \mathrm{O}_{\text {fluid }}$ values (Northrop and Clayton, 1966; O'Neil and Epstein, 1966; Sheppard and Schwarcz, 1970) are valid, then the model of dolomitization would most likely have to involve a mixture of meteoric and marine waters (mixing-zone dolomitization). Dolomitization within the mixing zone has been suggested by numerous authors (Badiozamani, 1973; Land, 1973; Ward and Halley, 1985; Humphrey, 1988; Stoessell et al., 1989; Cander, 1994; Humphrey, 2000), the driving force relying on the non-linear behavior of the activity of $\mathrm{Ca}^{2+}$ and $\mathrm{CO}_{3}{ }^{2-}$ causing the resultant mixtures of seawater and freshwater to be under saturated (saturation index $<0$ ) with respect to calcite (Figure 8) even if the original end members were at saturation or even over saturated (Badiozamani, 1973; Plummer, 1975). At the same time, dolomite remains oversaturated (saturation index $>0$ ) through most of this interval, thereby favoring the dissolution of calcite and aragonite and the formation of dolomite through the reaction shown in equation 4:

$$
2 \mathrm{CaCO}_{3}+\mathrm{Mg}^{2+}=\mathrm{CaMg}\left(\mathrm{CO}_{3}\right)_{2}+\mathrm{Ca}^{2+}
$$

While the chemical composition of the meteoric endmember varies depending upon the location and the nature of the local limestone, if it is assumed that the ground waters are saturated with respect to $\mathrm{LMC}$ and contain $0.01 \mathrm{mM} \mathrm{Mg}^{2+}$, then a mixture of groundwater with normal seawater would be saturated with respect to ordered dolomite $(\mathrm{pK}=18.06)$ (Carpenter, 1980) at compositions greater than $1 \%$ seawater. The fluids would therefore be oversaturated with respect to dolomite and undersaturated with respect to LMC between 1 and 21\% seawater, and undersaturated with respect to aragonite between 1 and 34\% (Figure 8). If instead the fluid precipitated a 'partially' ordered dolomite $(\mathrm{pK}=17)$ (Carpenter, 1980), the viable range for undersaturation with respect to aragonite while oversaturated with respect to dolomite is reduced to a mixture of only $15 \%$ to $34 \%$ seawater. This can be reduced even further to $15 \%$ to $25 \%$ if

512 considering LMC. Using these ranges and assuming a value of $-4 \%$ for meteoric water in the 513 Bahamas, similar the average value measured for rainfall on San Salvador (Baldini et al., 2007), 514 and a value of $+1 \%$ for seawater, then the range of expected $\delta^{18} \mathrm{O}_{\text {fluid }}$ values would lie between - 
2.25 and $-3.25 \%$. Outside of these ranges of fresh and seawater mixtures, the precipitation of 516 dolomite is no longer advantaged.

517 One of the major problems of the mixing-zone model is that in most studies on Modern 518 mixing-zones, no dolomite has ever been identified (Steinen and Matthews, 1973; Plummer et 519 al., 1976; Halley and Harris, 1979; Hardie, 1987; Stoessell et al., 1989). This suggests that despite the chemical benefits of the mixing zone, the kinetic barriers to dolomite formation are most likely still preventing formation in the Modern. Gaines (1980) even noted that the rate of 522 dolomitization would actually decrease in the presence of increasingly mixed fluids.

It has also been suggested that the mixing-zone model could not produce large volumes of dolomite and is instead more a source for localized dolomitization (Budd, 1997), unless there 525 is constant migration of the mixing zone throughout the dolomitized body (Humphrey and Quinn, 1989). This has led to multiple reviews (Plummer et al., 1976; Machel and Mountjoy, 1986; Hardie, 1987; Purser et al., 1994; Budd, 1997) suggesting that despite being chemically favorable, mixing-zone fluids do not address the other major inhibitors to dolomite formations, in particularly kinetic inhibitors, and instead is strictly an optimal thermodynamic point for dolomite formation.

From the perspective of the data presented in this work, we suggest it is unlikely that fluids from the mixing zone could have contributed to the positive trend between $\delta^{18} \mathrm{O}_{\text {fluid }}$ and temperature found in our samples. If some of our samples were to have formed from mixingzone fluids, then it would be expected that no trend would exist between the clumped-isotope temperatures and $\delta^{18} \mathrm{O}_{\text {fluid }}$ values as the $\delta^{18} \mathrm{O}_{\text {fluid }}$ value would be primarily controlled by the amount of mixing that is occurring between seawater and the freshwater lens.

The primary role of mixing-zone fluids in the Bahamas could have been the extensive dissolution of calcium carbonate due to the fluids being undersaturated with respect to calcite. The increasing porosity caused by the dissolution would thus increase fluid flow through the islands and the platform making it easier for seawater to supply $\mathrm{Mg}$ to the site of dolomitization (Plummer, 1975; Hardie, 1987; Beach, 1995). In addition, freshwater discharge through the base

543 providing a mechanism for driving normal seawater through the platform. This would produce a 544 model for the formation of the Bahamian dolomites that involved normal seawater as the dolomitizing fluid with the driving force for the fluids being a result of the discharge of 
546 freshwater through the mixing zone causing a concomitant flow of seawater (Land, 1991;

547 Vahrenkamp et al., 1991; Vahrenkamp and Swart, 1994), or through the process of Kohout convection (Simms, 1984; Whitaker and Smart, 1990; Whitaker and Smart, 1993; Frank and Bernet, 2000; Caspard et al., 2004).

If dolomitization takes place in normal seawater rather than in the mixing zone, the three equations which produced the more negative $\delta^{18} \mathrm{O}_{\text {fluid }}$ values can be excluded from consideration 552 (Northrop and Clayton, 1966; O'Neil and Epstein, 1966; Sheppard and Schwarcz, 1970). The 553 equations of Zheng (1999) and Horita (2014), both of which yield some negative $\delta^{18} \mathrm{O}_{\text {fluid }}$ values, 554 can similarly be disregarded. While current evidence does not support dolomitization by mixing zone fluids, if future evidence suggests that dolomitization in the mixing zone is a more viable option, these formulas should be reevaluated as possibilities. At the moment, we take the position that dolomitization from mixed fluids is not a viable option for any dolomite body and instead the mixing zone acts primarily as a mechanism to propel marine waters through the platform top.

Of the remaining three equations, we have excluded those of Fritz and Smith (1970) and Vasconcelos et al. (2005) as they included precipitated Ca-Mg carbonates that did not exhibit the high degree of ordering found in true dolomites (Gregg et al., 2015). However, with respect to

563 clumped isotopes, no study has found a significant difference in the relationship between

564 carbonate mineralogy and the relationship between $\Delta_{47}$ and precipitation temperature (Defliese et 565 al., 2015; Bonifacie et al., 2016). In Murray et al. (2016), it was also shown that the 566 stoichiometry of a dolomite had no impact on its $\Delta_{47}$ acid digestion fractionation. Therefore, 567 although the clumped-isotope temperatures are likely not influenced by the stoichiometry and 568 order of a dolomite relative to a very high $\mathrm{Mg}$-calcite, there is evidence suggesting these factors 569 influence the $\delta^{18} \mathrm{O}$ value of the carbonate (Vahrenkamp and Swart, 1994) thus eliminating the 570 equations of Fritz and Smith (1970) and Vasconcelos et al. (2005) from consideration for the 571 ordered dolomites used this study and with respect to their use in future studies. This leaves only 572 the calibration of Matthews and Katz (1977), which yielded $\delta^{18} \mathrm{O}_{\text {fluid }}$ values for all of the 573 Bahamian dolomites from +0.5 to $+3.5 \%$, a range which we consider to be realistic considering 574 the various constraints on the fluids already discussed. This range of values is similar to those 575 calculated from clumped-isotope temperatures measured on Andros Island, Bahamas ( + 2\%o) 576 from dolomites collected in the shallow sections of a core (Winkelstern and Lohmann, 2016). 
577 However, in that work, the authors opted to use the calibration of Horita (2014) to calculate their

578 fluid values. Re-calculating their $\delta^{18} \mathrm{O}_{\text {fluid }}$ values with Matthews and Katz (1977), the $\delta^{18} \mathrm{O}_{\text {fluid }}$

579 values would increase by $\sim 1 \%$ which is still within range of normal Bahamian fluids. It is

580 therefore concluded that over the range of temperatures the Bahamian dolomites formed under

581 ( $\sim 15$ to $35^{\circ} \mathrm{C}$ ), the equation of Matthews and Katz (1977) produces the most realistic $\delta^{18} \mathrm{O}_{\text {fluid }}$ 582 values.

583 Whereas the lower range of the fluid values calculated using Matthews and Katz (1977)

584 is consistent with Bahamian seawater, a single fluid source is unable to explain the $\sim 3 \%$ range or

585 the strong covariation with temperature, thus suggesting that the Bahamian dolomites formed

586 from an array of derivatives of normal seawater that have undergone varying amounts of

587 evaporation.

\section{Constraints of the Formation Mechanisms}

the following section explores the implications that these values have on the refinement of dolomitization models that have been proposed in the Bahamas.

\section{Little Bahama Bank}

594 The dolomites sampled from both GB2 and $\mathrm{WC} 1$ have similar $\delta^{13} \mathrm{C}$ and $\delta^{18} \mathrm{O}$ values as 595 well as clumped-isotope temperatures. The $\delta^{18} \mathrm{O}_{\text {dolomite }}$ value in both cores is $\sim+3 \%$ with the 596 WC1 samples containing small amounts of calcite having a lower bulk $\delta^{18} \mathrm{O}$ value. Such a $597 \quad \delta^{18} \mathrm{O}_{\text {dolomite }}$ value would be typical for formation by normal marine seawater corresponding to $598 \delta^{18} \mathrm{O}_{\text {calcite }}$ values of $0 \%$. The $\delta^{13} \mathrm{C}_{\text {dolomite }}$ value is stable in both cores at $+2 \%$ before decreasing to $599-3 \%$ in the upper $10 \mathrm{~m}$. This has been attributed to a mixed diagenetic signal and a greater 600 incorporation of LMC in the bulk sediment (Vahrenkamp and Swart, 1994). The clumped601 isotope temperatures lay within a narrow range in both cores $\left(18\right.$ to $\left.25^{\circ} \mathrm{C}\right)$, with a few outliers 602 present (Figure 9), and is similar to temperatures of normal Modern seawater in the Bahamas 603 (Slowey and Curry, 1995). The relative consistency of the $\delta^{18} \mathrm{O}, \delta^{13} \mathrm{C}$, and clumped-isotope 604 values between the two cores suggests a common dolomitizing fluid, in agreement with previous 605 studies on these cores (Williams, 1985; Vahrenkamp, 1988; Vahrenkamp et al., 1991;

606 Vahrenkamp and Swart, 1994). 
The calculated $\delta^{18} \mathrm{O}_{\text {fluid }}$ value suggests fluids with compositions between +0.7 and $+2.5 \%$ o

608 in both cores. The average $\delta^{18} \mathrm{O}_{\text {fluid }}$ values are $+1.4 \pm 0.5 \%$ and $+1.6 \pm 0.6 \%$ for the GB2 and

609 WC1 cores respectively. Such values are typical for normal seawaters found in the Bahamas

610 (Epstein and Mayeda, 1953; Shinn et al., 1989; Swart, 2000; Swart et al., 2009). The presence of

611 calcite in some of the WC1 samples has skewed the calculated $\delta^{18} \mathrm{O}_{\text {fluid }}$ values for these samples

612 to outside this range, although that is most likely an effect of trying to compensate for the

613 presence of calcite in the calculation by using a linear mixing model between the dolomite and

614 calcite fluid calibrations. There is an increasing trend in $\delta^{18} \mathrm{O}_{\text {fluid }}$ values with depth in the GB2

615 core that is not evident in the WC1 core. This could be a result of under sampling in GB2 or the

616 samples with mixed calcite and dolomite at the top of the WC1 core confusing the trend.

617 Considering the small size of LBB relative to GBB and the parallel isotopic signals between the

618 two cores, the requisite model of dolomitization is likely to be similar at both locations or

619 include a bank encompassing fluid flow. Based on the relatively low clumped-isotope

620 temperatures $\left(<20^{\circ} \mathrm{C}\right)$ of some of the samples relative to Bahamas surface fluids, the influx of

621 bottom waters by Kohout convection could account for a bank wide dolomitization and also

622 explain colder fluid temperatures calculated by clumped isotopes. The range of fluid

623 compositions of WC1 and GB2, are larger than in Unda but not as large as San Salvador (Table

624 2) and suggests a greater contribution from evaporative fluids for these dolomites than those in

625 which Unda formed. This would imply some contribution from sea-surface fluids, most likely

626 contributed through density reflux of evaporative pools or restricted water from LBB. The

627 partially dolomitized section of WC1 could be attributed to periods of freshwater discharge

628 driving seawater influx as it is active for a shorter period of time and would not be expected to

629 dolomitize large portions of the bank.

$630 \underline{\text { Unda }}$

631 The $\delta^{13} \mathrm{C}$ values in Unda decrease up section from +3.2 to $+2.2 \%$. This same trend is not

632 visible in the larger data set from the same core shown in Melim et al. (2001), thus suggesting

633 that this trend is most likely a result of sampling bias in this study. The $\delta^{18} \mathrm{O}_{\text {dolomite }}$ values are

634 fairly constant throughout the sampled section, ranging from +2.6 to $+3.0 \%$. The clumped-

635 isotope temperatures are lower than both San Salvador and Little Bahama Bank, ranging from 16

636 to $19^{\circ} \mathrm{C}$ with an average of $18 \pm 1^{\circ} \mathrm{C}$, in good agreement with earlier interpretations that the

637 Unda core formed in deeper, cooler, waters than both the San Salvador and the LBB cores. 
The calculated $\delta^{18} \mathrm{O}_{\text {fluid }}$ values suggest the dolomitizing fluids ranged in composition from +0.5 to $+1.7 \%$, with an average value of $+1.2 \pm 0.3 \%$. This is within range of formation by normal marine fluids. These results require a fluid flow mechanism not only active at depth, but also probably limited spatially, otherwise it would be expected that a larger portion of the core would have been dolomitized instead of just the reefal section. An active mixing zone could have driven sea-water influx with the restriction coming from the depth of the fresh water lens. This is appealing due to the presence of a sub-aerial exposure surface capping the majority of the fully dolomitized section suggesting that after deposition the mixing zone would have passed through these sediments. The principle argument against this is that colder clumped-isotope temperatures would have not been produced from the surface fluids drawn in by fluids associated with the mixing zone. However, the depth of the mixing zone can vary depending on the size of the fresh water lens, so it is possible that colder fluids occurred deeper in the section. Sub-aerial exposure is also indicative of glacio-eustatic sea level change which, as a fluid driver, was modeled to have formed a gravity-driven flow of pore waters beneath the formation of a freshwater lens (Simms, 1984). A secondary control would be the rate of sea level rise after the sub aerial exposure surface as an initially slower rate would have allowed for an extended period of influx that would have diminished if the rate increased. Fluctuating rates of sea level change could have allowed more time for dolomitization in specific sections of the core and less in others explaining the partial dolomitization of portions of the core. The other alternative for preferential dolomitization is increased porosity and permeability associated with the reefal sediments that compose the fully dolomitized section. These could have acted as a conduit for increased fluid flow relative to the rest of the core therefore preferentially dolomitizing this section.

$\underline{\text { San Salvador }}$

The dolomitized portion of San Salvador suggests formation from fluids ranging between 662 normal marine seawater $(+0.3 \%)$ and evaporative saline fluids $(+3.9 \%)$. These are the most 663 positive $\delta^{18} \mathrm{O}_{\text {fluid }}$ values of any of the Bahamian samples, perhaps suggesting a slightly different 664 mechanism of dolomitization compared to GBB and LBB.

Within a single deepening then shallowing sea-level cycle (between 54.2and $66.9 \mathrm{~m}$ depth), capped at the top and bottom by exposure surfaces, Figure 10 shows that there are

667 slightly elevated temperatures and $\delta{ }^{18} \mathrm{O}_{\text {fluid }}$ values at the tail-ends of the cycle. This suggests 668 interaction with warm-evaporative fluid input during low-stands. Towards the middle of the 
669 cycle, both the temperature and the $\delta^{18} \mathrm{O}_{\text {fluid }}$ values decrease suggesting a greater input from 670 normal marine seawater. Such trends imply a downward flux of saline fluids during periods of 671 low sea level, possibly originating from shallow saline ponds found on many of the modern 672 islands in the Bahamas, including San Salvador.

673 Insight into the process can be obtained by examining the shallow pools of Modern San

674 Salvador island which are fed by the surrounding ocean and have elevated temperatures

675 (Pinckney et al., 1995; Dalman, 2009) and $\delta^{18} \mathrm{O}_{\text {fluid }}$ values. While direct measurements of the 676 fluids on San Salvador have not been performed, analyses from similar evaporative pools in the 677 Bahamas such as Little Darby Island, Lee Stocking Island, and Eleuthera have measured $\delta^{18} \mathrm{O}$ 678 values between +1.3 and $+4.9 \%$ (Figure 11). In the case of Little Darby, dolomite has been 679 found immediately beneath the ponds surface (Piggot, 2014). The reflux mechanism has been 680 shown to exist on GBB (Whitaker and Smart, 1990; Whitaker and Smart, 1993) and has been 681 suggested to be a viable fluid driver with increases in salinity of as little as 37 to $42 \%$ (Simms, 682 1984). Measurements of salinity in Salt Pond, one of the many evaporative pools on San 683 Salvador, showed salinity variations in the pool from 20 to 356\% (Shamberger and Foos, 2004) 684 with the vast majority of measurements suggesting the fluid in the pond would be capable of 685 reflux flow.

686 Based on the clumped-isotope temperatures and calculated fluid composition, a reflux 687 type model involving these evaporative pools is the favored mechanism of dolomitization for the 688 majority of the core compared to other proposed fluid models including dolomitization in the 689 mixing zone (Supko, 1977) and Kohout convection (Dawans and Swart, 1988). However, the 690 data from the 54.2 to $66.9 \mathrm{~m}$ section does suggest a period of time when dolomitization was 691 dominantly associated with a more normal seawater type fluid. This could have been 692 accomplished during periods of elevated sea level when the ponds on the island would be 693 unrestricted and the amount of reflux would have been reduced. During such a time, other fluid 694 flow models, such as Kohout convection, would dominate the circulation of fluid within the 695 island. This model is supported by the Sr-isotope data of Swart et al. (1987) and Vahrenkamp et 696 al. (1991) where it was shown that the portion of the core between 54.2 to $66.9 \mathrm{~m}$ was 697 considerably younger than other portions of the core. The age date of less than $150 \mathrm{ka}$ for the 69854.2 to $66.9 \mathrm{~m}$ section opens up the possibility of formation during marine isotope stage 5E. 


\section{Conclusions}

In this study, it is suggested that the use of geologically well constrained dolomites favors the dolomite-fluid equation proposed by Matthews and Katz (1977). Excluding calibrations

703 based on very-high Mg-calcite samples (Fritz and Smith, 1970; Vasconcelos et al., 2005), this

704 was the only one of the eight equations tested that produced $\delta^{18} \mathrm{O}_{\text {fluid }}$ values greater than $0 \%$ for all pure dolomite samples from these cores. However, this study only covers a temperature range of $\sim 15$ to $35^{\circ} \mathrm{C}$ in dolomite formation temperatures, and while the Matthews and Katz (1977) equation appears to best represent these low temperature dolomites from the Bahamas, it is not necessarily the best equation for higher temperature dolomites.

With knowledge of the fluid composition of the Bahamian dolomites, we have reevaluated the mechanism of dolomitization of these sediments. The fluids involved in the dolomite formation on LBB were probably derived from normal marine seawaters driven by a combination of bank-wide Kohout convection, or the more restricted flows of seawater influx associated with the mixing zone in conjunction with hypersaline reflux. The Unda dolomite also formed from normal seawater, but at a slightly greater depth and from more consistently colder fluids when compared to LBB. Dolomitization probably occurred by seawater driven by the mixing zone during a period of low-stand sea level taking advantage of the porosity and permeability of the reefal sediments. On San Salvador, the bulk of dolomitization can be attributed to reflux-migrating fluids derived from the evaporative pools with $\delta^{18} \mathrm{O}_{\text {fluid }}$ between +2.5 and $+3.9 \%$ and temperatures exceeding $30^{\circ} \mathrm{C}$ on the surface of the island. A section of the core between 54.2 to $66.9 \mathrm{~m}$ depth below sea surface has a different signal with $\delta^{18} \mathrm{O}_{\text {fluid }}$ and

721 temperatures more closely resembling normal marine seawater. This section was dolomitized

722 significantly later age than the rest of the core, probably during marine isotope stage 5.

The data presented here suggests that there may have been several mechanisms of

724 dolomite formation operating simultaneously and/or synchronously to dolomitize the Bahamas

725 from the late Miocene to the Modern. No single model can directly explain the range of $\delta^{18} \mathrm{O}_{\text {fluid }}$ 726 values or the correlation between increasing clumped-isotope temperatures and $\delta^{18} \mathrm{O}_{\text {fluid }}$ values.

\section{Acknowledgments}

This work was supported by ACS grant PRF\# 52863-ND2, the Stable Isotope Laboratory and the Center of Carbonate Research Comparative Sedimentology Laboratory at the University of Miami. The Unda core was collected under NSF grant OCE-8917295 to PKS and R.N. Ginsburg. Funding for the MAT 253 was provided by NSF grant EAR-0926503 to PKS. The authors would also like to thank Greta Mackenzie for editorial help as well as the reviewers and 
733 Hagit Affek for their insightful comments that improved early drafts of this manuscript. Phillip 734 Staudigel aided in the use of the Ocean Data View program. 


\section{Figure Captions}

738 Figure 1 - The eight different formulas proposed for relating $\delta^{18} \mathrm{O}_{\text {dolomite }}$ values to temperature and the composition of the fluid plotted as temperature of formation against $1000 * \ln (\alpha)$. Note the large range $(\sim 3.6 \%$ o of values for $1000 * \ln (\alpha)$ for any individual temperature that can be produced. This range is large enough that the interpretation of dolomite formation becomes contingent upon which formula is chosen.

Figure 2 - Map of the Bahamas identifying the various core locations used in this study for clumped isotope analysis. Both WC1 and GB2 are located on Little Bahama Bank, Unda is located on the Western edge of Great Bahama Bank, and San Salvador is on the Eastern edge of the Bahamas. Little Darby and Eleuthera are locations where evaporative pond waters have been analyzed for $\delta^{18} \mathrm{O}_{\text {fluid. }}$

Figure 3 - Illustrations of three likely mechanisms that contributed to the formation of dolomites in the Bahamas. A) Kohout convection, B) coastal mixing of fresh surface waters and a compensatory flow of marine water, $\mathrm{C}$ ) evaporative brine reflux.

Figure 4 - Petrographic and dolomite textural description of the four Bahamian cores used in this study. Descriptions are based on previous studies of these cores: San Salvador (Dawans and Swart, 1988); WC1 and GB2 (Vahrenkamp and Swart, 1994); Unda (Swart and Melim, 2000).

Figure 5 - Carbon and oxygen isotopes for the cores from Little Bahama Bank. Error bars represent $\pm 1 \sigma$ although they are typically smaller than the symbol size. Data not indicated as being from this study are taken from the work of Vahrenkamp and Swart (1994). Oxygen isotopes have been corrected for the difference in acid digestion fractionation between LMC and dolomite of $-0.8 \%$ based on the bulk \% dolomite present in the sample determined by X-ray diffraction. The sudden change in isotopic composition is associated with a change in mineralogy from calcite to dolomite.

Figure 6 -Eight plots of the $\delta^{18} \mathrm{O}_{\text {dolomite }}$ against temperature of formation from clumped isotopes for all four Bahamian cores. The contours represent different values of $\delta^{18} \mathrm{O}_{\text {fluid }}(\%$, VSMOW) as calculated using the eight different $\delta^{18} \mathrm{O}_{\text {dolomite-fluid }}$ calibrations, including A) Northrop and Clayton (1966), B) O’Neil and Epstein (1966), C) Sheppard and Schwarz (1970), D) Fritz and Smith (1970), E) Matthews and Katz (1977), F) Zheng (1999), G) Vasconcelos et al. (2005), and H) Horita (2014). Based on a geological context, any calibration that had a significant portion of the $\delta^{18} \mathrm{O}_{\text {fluid }}$ values falling below the $0 \%$ o line (red) was considered invalid due to the implied interpretation of dolomitization by fresh water. Error bars represent $\pm 1 \sigma$ of replicates.

Figure 7 - Individual plots of $\delta^{18} \mathrm{O}_{\text {dolomite }}$ values against the calculated $\delta^{18} \mathrm{O}_{\text {fluid }}$ values using Matthews and Katz (1977) for each of the four Bahamian cores used in this study. Average clumped-isotope temperatures are represented by changing color with blue being the coldest temperatures measured in that core and red being the warmest. To better show trends, the temperature scales are independent for each core and error bars have been excluded (errors for 780 each measurement can be found in the supplementary material), however, and average error of 781 all the samples from each individual core is presented. Note how in each core there is a limited 
782 range of $\delta^{18} \mathrm{O}_{\text {dolomite }}$ values over a range of $\delta^{18} \mathrm{O}_{\text {fluids }}$ values with no recognizable trend between 783 the two variables, but there is a strong trend of increasing temperature with increasing $\delta^{180}$ fluids 784 values.

Figure 8 - Theoretical saturation relationships for both ordered $(\mathrm{pK}=18.06)$ and disordered $(\mathrm{pK}=$ 17.00) dolomite (Carpenter, 1980) as well as low-Mg calcite $(\mathrm{pK}=8.48)$ and aragonite $(\mathrm{pK}=$ 8.34) (Plummer and Busenberg, 1982) assuming a groundwater with $0.01 \mathrm{mM} \mathrm{Mg}^{2+}$. Notice how the mixed fluid is rapidly saturated with respect to dolomite with little seawater input. Only with greater amounts of mixing does it eventually become saturated with respect to calcite and then aragonite.

Figure 9 - Calculated clumped-isotope temperatures $( \pm 1 \sigma)$ relative to depth for the cores in this study. The gray rectangles represent the typical yearly range of seawater temperature in the Bahamas.

Figure 10 - Zoomed in section of the San Salvador core between two subaerial exposure horizons (yellow squiggles) interpreted to be a deepening upwards sea-level cycle. The clumpedisotope temperatures and $\delta^{18} \mathrm{O}_{\text {fluid }}( \pm 1 \sigma)$ both show a trend of elevated values during the shallow ends of the cycle and reduced values when sea level was high.

Figure 11 - Plot of the calculated clumped-isotope temperatures and $\delta^{18} \mathrm{O}_{\text {fluid }}$ values using the Matthews and Katz (1977) calibration. This plot shows the large range of fluids that formed the Bahamian dolomites in this study. The blue square represents normal marine seawaters in the Bahamas, drawn based on the surface seawater temperature range in the Bahamas and average $\delta^{18} \mathrm{O}_{\text {fluid }}$ values $( \pm 1 \sigma)$ measured off Great Bahama Bank (Swart et al., 2009). The red square is indicative of the evaporative pools found on Bahamian islands with the range of temperatures from Pickney et al. (1997) and Dalman (2009) and the $\delta^{18} \mathrm{O}_{\text {fluid }}$ range based on the average measured values $( \pm 1 \sigma)$ from evaporative
Error bars have been omitted for clarity. 


\section{References}

813 Arvidson, R.S., Mackenzie, F.T., 1999. The dolomite problem: control of precipitation kinetics

814 by temperature and saturation state. American Journal of Science 299, 257-288.

815 Badiozamani, K., 1973. Dorag dolomitization model-application to middle Ordovician of 816 Wisconsin. Journal of Sedimentary Petrology 43, 965-984.

817 Baldini, L.M., Walker, S.E., Railsback, L.B., Baldini, J.U.L., Crowe, D.E., 2007. Isotopic 818 ecology of the modern land snail Cerion, San Salvador, Bahamas: Preliminary advances toward 819 establishing a low-latitude island paleoenvironmental proxy. PALAIOS 22, 174-187.

820 Beach, D.K., 1995. Controls and effects of Saubaerial exposure on cementation and development of secondary porosity in the subsurface of Great Bahama Bank, in: Budd, D.A., Saller, A.H., Harris, P.M. (Eds.), Unconformities and Porosity in Carbonate Strate. The American

824 Beach, D.K., Ginsburg, R.N., 1980. Facies succession of Pliocene-Pleistocene carbonates, Northwestern Great Bahama Bank. The American Association of Petroleum Geologists Bulletin 64, 1634-1642.

827 Bonifacie, M., Calmels, D., Eiler, J.M., Horita, J., Chaduteau, C., Vasconcelos, C., Agrinier, P., 828 Katz, A., Passey, B.H., Ferry, J.M., Bourrand, J.-J., 2016. Calibration of the dolomite clumped 829 isotope thermometer from 25 to $350^{\circ} \mathrm{C}$, and implications for a universal calibration for all $(\mathrm{Ca}$, $830 \mathrm{Mg}, \mathrm{Fe}) \mathrm{CO} 3$ carbonates. Geochimica et Cosmochimica Acta.

831 Brand, W.A., Assonov, S.S., Coplen, T.B., 2010. Correction for the ${ }^{17} \mathrm{O}$ interference in $\delta\left({ }^{13} \mathrm{C}\right)$ 832 measurements when analyzing $\mathrm{CO} 2$ with stable isotope mass spectrometry (IUPAC Technical 833 Report)*. Pure Applied Chemistry 82, 1719-1733.

834 Budd, A.F., Manfrino, C., 2001. Coral assemblages and reef environments in the Bahamas 835 Drilling Project cores, in: Ginsburg, R.N. (Ed.), Subsurface Geology of a Prograding Carbonate 836 Platform Margin, Great Bahama Bank: Results of the Bahamas Drilling Project. SEPM, SEPM 837 Special Publications, pp. 41-59.

838 Budd, D.A., 1997. Cenozoic dolomites of carbonate islands: their attributes and origin. Earth 839 Science Reviews 42, 1-47.

840 Burke, W.H., Denison, R.E., Hetherington, E.A., Koepnick, R.B., Nelson, H.F., Otto, J.B., 1982. 841 Variation of seawater ${ }^{87} \mathrm{Sr} /{ }^{86} \mathrm{Sr}$ throughout Phanerozoic time. Geology 10, 516-519.

842 Came, R.E., Brand, U., Affek, H.P., 2014. Clumped isotope signatures in modern brachiopod 843 carbonate. Chemical Geology 377, 20-30.

844 Cander, H.S., 1994. An example of mixing-zone dolomite, middle Eocene Avon Park Formation, 845 Floridan Aquifer system. Journal of Sedimentary Research 64.

846 Carpenter, A.B., 1980. The chemistry of dolomite formation 1: The stability of dolomite. SEPM 847 Special Publication 28, 111-121. 
Caspard, E., Rudkiewicz, J.L., Eberli, G.P., Brosse, E., Renard, M., 2004. Massive

dolomitization of a Messinian reef in the Great Bahama Bank: a numerical modelling evaluation of Kohout geothermal convection. Geofluids 4, 40-60.

851 Craig, H., 1957. Isotopic standards for carbon and oxygen and correction factors for mass 852 spectrometric analysis of carbon dioxide. Geochimica et Cosmochimica Acta 12, 133-149.

853 Daëron, M., Blamart, D., Peral, M., Affek, H., 2016. Absolute isotopic abundance ratios and the 854 accuracy of $\Delta_{47}$ measurements. Chemical Geology.

855 Daëron, M., Guo, W., Eiler, J.M., Genty, D., Blamart, D., Boch, R., Drysdale, R., Maire, R., 856 Wainer, K., Zanchetta, G., 2011. ${ }^{13} \mathrm{C}^{18} \mathrm{O}$ clumping in speleothems: Observations from natural 857 caves and precipitation experiments. Geochimica et Cosmochimica Acta 75, 3303-3317.

858 Dalman, M., 2009. Paleotempestology and depositional history of Clear Pond, San Salvador

860 Dawans, J.M., Swart, P.K., 1988. Textural and geochemical alterations in Late Cenozoic 861 Bahamian dolomites. Sedimentology 35, 385-403.

Defliese, W.F., Hren, M.T., Lohmann, K.C., 2015. Compositional and temperature effects of 863 phosphoric acid fractionation on $\Delta 47$ analysis and implications for discrepant calibrations.

864 Chemical Geology 396, 51-60.

865 Defliese, W.F., Lohmann, K.C., 2015. Non-linear mixing effects on mass-47 $\mathrm{CO}_{2}$ clumped 866 isotope thermometry: Patterns and implications. Rapid Communication Mass Spectrometry 29, 867 901-909.

868 Degens, E.T., Epstein, S., 1964. Oxygen and carbon isotope ratios in coexisting calcites and 869 dolomites from recent and ancient sediments. Geochimica et Cosmochimica Acta 28, 23-44.

870 Dennis, K.J., Affek, H., Passey, B.H., Schrag, D.P., Eiler, J.M., 2011. Defining an absolute 871 reference frame for 'clumped' isotope studies of $\mathrm{CO}_{2}$. Geochimica et Cosmochimica Acta 75, 872 7117-7131.

873 Dennis, K.J., Schrag, D.P., 2010. Clumped isotope thermometry of carbonatites as an indicator 874 of diagenetic alteration. Geochimica et Cosmochimica Acta 74, 4110-4122.

875 DePaolo, D.J., 1986. Detailed record of the Neogene Sr isotopic evolution of seawater from 876 DSDP Site 590B. Geology 14, 103-106.

877 Eagle, R.A., Eiler, J.M., Tripati, A.K., Ries, J.B., Freitas, P.S., Hiebenthal, C., Wanamaker Jr., 878 A.D., Taviani, M., Elliot, M., Marenssi, S., Nakamura, K., Ramirez, P., Roy, K., 2013. The 879 influence of temperature and seawater carbonate saturation state on ${ }^{13} \mathrm{C}-{ }^{18} \mathrm{O}$ bond ordering in 880 bivalve mollusks. Biogeosciences 10, 4591-4606. 
Eagle, R.A., Schauble, E.A., Tripati, A.K., Tutken, T., Hulbert, R.C., Eiler, J.M., 2010. Body

882 Temperatures of Modern and Extinct Vertebrates from ${ }^{13} \mathrm{C}-{ }^{18} \mathrm{O}$ bond abundances in bioapetite.

883 National Acedemy of Sciences, Proceedings 107, 10377- 10382.

884 Epstein, S., Mayeda, T., 1953. Variation of $\mathrm{O}^{18}$ content of waters from natural sources.

885 Geochimica et Cosmochimica Acta 4, 213-224.

886 Fernandez, A., Tang, J., Rosenheim, B.E., 2014. Siderite 'clumped' isotope thermometry: A new

887 paleoclimate proxy for humid continental environments. Geochimica et Cosmochimica Acta 126, 888 411-421.

889 Frank, T.D., Bernet, K., 2000. Isotopic signature of burial diagenesis and primary lithological 890 contrasts in periplatform carbonates (Miocene, Great Bahama Bank). Sedimentology 47, 11198911134.

892 Friedman, I., Hall, W.E., 1963. Fractionation of $\mathrm{O}^{18} / \mathrm{O}^{16}$ between coexisting calcite and dolomite. 893 The Journal of Geology 71, 238-243.

894 Friedman, I., O'Neil, J.R., 1977. Compilation of stable isotope fractionation: Factors of 895 geochemical interest, in: Fleischer, M. (Ed.), Data of Geochemistry 6th ed. Geology Survey Prof. 896 Paper. USGS, Washington DC.

897 Fritz, P., Smith, D.G.W., 1970. The isotopic composition of secondary dolomites. Geochimica et 898 Cosmochimica Acta 34, 1161-1173.

899 Gaines, A.M., 1980. Dolomitization kinetics: recent experimental studies. SEPM Special 900 Publication 28, 81-86.

901 Ghosh, P., Adkins, J., Affek, H., Balta, B., Guo, W., Schauble, E.A., Schrag, D., Eiler, J.M., $9022006 .{ }^{13} \mathrm{C}-{ }^{18} \mathrm{O}$ bonds in carbonate minerals: A new kind of paleothermometer. Geochimica et 903 Cosmochimica Acta 70, 1439-1456.

904 Ghosh, P., Eiler, J.M., Campana, S.E., Feeney, R.F., 2007. Calibration of the carbonate 'clumped 905 isotope' paleothermometer for otoliths. Geochimica et Cosmochimica Acta 71, 2736-2744.

906 Gonfiantini, R., Stichler, W., Rozanski, K., 1993. Standards and intercomparison materials 907 distributed by the International Atomic Energy Agency for stable isotope measurements, 908 International Atomic Energy Agency, Vienna.

909 Goodell, H.G., Garman, R.K., 1969. Carbonate geochemistry of Superior deep test well, Andros 910 Island, Bahamas. AAPG Bulletin 53, 513-536.

911 Grauel, A.-L., Schmid, T.W., Hu, B., Bergami, C., Capotondi, L., Zhou, L., Bernasconi, S.M., 912 2013. Calibration and application of the 'clumped isotope' thermometer to foraminifera for high913 resolution climate reconstructions. Geochimica et Cosmochimica Acta 108, 125-140. 
914 Gregg, J.M., Bish, D.L., Kaczmarek, S.E., Machel, H.G., 2015. Mineralogy, nucleation and 915 growth of dolomite in the laboratory and sedimentary environment: A review. Sedimentology, 191621.

917 Halley, R.B., Harris, P.M., 1979. Fresh-water cementation of a 1,000-year-old oolite. Journal of 918 Sedimentary Research 49.

919 Hardie, L.A., 1987. Dolomitization - A critical-view of some current views. Journal of 920 Sedimentary Petrology 57, 166-183.

921 He, B., Olack, G.A., Colman, A.S., 2012. Pressure baseline correction and high-precision $\mathrm{CO}_{2}$ 922 clumped-isotope $\left(\Delta_{47}\right)$ measurements in bellows and micro-volume modes. Rapid

923 Communication Mass Spectrometry 26, 2837-2853.

924 Hearty, P.J., Kindler, P., 1995. Sea-level highstand chronology from stable carbonate platforms 925 (Bermuda and the Bahamas). Journal of Coastal Research 11, 675-689.

926 Henkes, G.A., Passey, B.H., Wanamaker Jr., A.D., Grossman, E.L., Ambrose Jr., W.G., Carroll, 927 M.L., 2013. Carbonate clumped isotope compositions of modern marine mollusk and brachiopod 928 shells. Geochimica et Cosmochimica Acta 106, 307-325.

929 Horita, J., 2014. Oxygen and carbon isotope fractionation in the system dolomite-water- $\mathrm{CO}_{2}$ to 930 elevated temperatures. Geochimica et Cosmochimica Acta 129, 111-124.

931 Horita, J., Clayton, R.N., 2007. Comment on the studies of oxygen isotope fractionation between 932 calcium carbonates and water at low temperatures by Zhou and Zheng (2003; 2005). Geochimica 933 et Cosmochimica Acta 71, 3131-3135.

934 Humphrey, J.D., 1988. Late Pleistocene mixing zone dolomitization, southeastern Barbados, 935 West Indies. Sedimentology 35, 327-348.

936 Humphrey, J.D., 2000. New geochemical support for mixing-zone dolomitization at Golden 937 Grove, Barbados. Journal of Sedimentary Research 70, 1160-1170.

938 Humphrey, J.D., Quinn, T.M., 1989. Coastal mixing zone dolomite, forward modeling, and 939 massive dolomitization of platform-margin carbonates. Journal of Sedimentary Research 59.

940 Huntington, K.W., Eiler, J.M., Affek, H., Guo, W., Bonifacie, M., Yeung, L.Y., Thiagarajan, N., 941 Passey, B.H., Tripati, A.K., Daëron, M., Came, R., 2009. Methods and limitations of 'clumped' $942 \mathrm{CO}_{2}$ isotope $\left(\Delta_{47}\right)$ analysis by gas-source isotope ratio mass spectrometry. Journal of Mass 943 Spectrometry.

944 Kaldi, J., Gidman, J., 1982. Early diagenetic dolomitic cements-Examples from the Permian 945 lower Magensian Limestone of England and the Pleistocene carbonates of the Bahamas. Journal 946 of Sedimentary Petrology 52, 1073-1085.

947 Kele, S., Breitenbach, S.F.M., Capezzuoli, E., Meckler, A.N., Ziegler, M., Millan, I.M., Kluge, 948 T., Deák, J., Hanselmann, K., John, C.M., Yan, H., Liu, Z., Bernasconi, S.M., 2015. Temperature 
dependence of oxygen- and clumped isotope fractionation in carbonates: A study of travertines and tufas in the $6-95{ }^{\circ} \mathrm{C}$ temperature range. Geochimica et Cosmochimica Acta 168, 172-192.

951 Kelson, J.R., Huntington, K.W., Schauer, A.J., Saenger, C., Lechler, A.R., 2016. Toward a 952 Universal Carbonate Clumped Isotope Calibration: Diverse Synthesis and Preparatory Methods 953 Suggest a Single Temperature Relationship. Geochimica et Cosmochimica Acta.

954 Kenter, J.A.M., Ginsburg, R.N., Troelstra, S.R., 2001. Sea-level driven sedimentation patterns on the slope and margins, in: Ginsburg, R.N. (Ed.), Subsurface geology of a prograding carbonate platform margin, Great Bahama Bank: Results of the Bahamas drilling project. Society for

958 Kim, S.-T., O'Neil, J.R., 1997. Equilibrium and nonequilibrium oxygen isotope effects in 959 synthetic carbonates. Geochimica et Cosmochimica Acta 61, 3461-3475.

960 Kluge, T., John, C.M., Jourdan, A.-L., Davis, S., Crawshaw, J., 2015. Laboratory calibration of 961 the calcium carbonate clumped isotope thermometer in the $25-250^{\circ} \mathrm{C}$ temperature range.

962 Geochimica et Cosmochimica Acta.

963 Kohout, F.A., 1967. Groundwater flow and the geothermal regime of the Floridian Plateau.

964 Transactions of the Gulf Coast Assoc. of Geol. Societies XVII.

965 Land, L., 1991. Dolomitization of the Hope Gate Formation (north Jamaica) by seawater: 966 reassessment of mixing-zone dolomite. Stable Isotope Geochemistry: A Tribute to Samuel 967 Epstein: The Geochemical Society [London], Special Publication 3, 121-130.

968 Land, L.S., 1973. Holocene meteoric dolomitization of Pleistocene limestones, North Jamaica. 969 Sedimentology 20, 411-424.

970 Land, L.S., 1980. The isotopic and trace element geochemistry of dolomite: The state of the art. 971 SEPM Special Publication 28, 87-110.

972 Land, L.S., 1983. The application of stable isotopes to studies of the origin of dolomite and to 973 problems of diagenesis of clastic cements, Stable Isotopes in Sedimentary Geology pp. 1-75.

974 Land, L.S., 1998. Failure to precipitate dolomite at $25{ }^{\circ} \mathrm{C}$ from dilute solution despite 1000 -fold 975 oversaturation after 32 years. Aquatic Geochemistry 4, 361-368.

976 Machel, H.-G., Mountjoy, E.W., 1986. Chemistry and environments of dolomitization - a 977 reappraisal. Earth Science Reviews 23, 175-222.

978 Matthews, A., Katz, A., 1977. Oxygen isotope fractionation during the dolomitization of calcium 979 carbonate. Geochimica et Cosmochimica Acta 41, 1431-1438.

980 McNeill, D.F., 1989. Magnetostratigraphic dating and magnetization of cenozoic platform 981 carbonates from the Bahamas. Dissertation. Marine Geology and Geophysics, University of 982 Miami - Rosenstiel School of Marine and Atmospheric Science. 210 
McNeill, D.F., Ginsburg, R.N., Chang, S.-B.R., Kirschvink, J.L., 1988. Magnetostratigraphic dating of shallow-water carbonates from San Salvador Bahamas. Geology 16, 8-12.

McNeill, D.F., Lidz, B.H., Swart, P.K., Kenter, J.A.M., 2001. Chronostratigraphy of a prograded carbonate platform margin: A record of dynamic slope sedimentation Western Great Bahama Bank, Subsurface Geology of a Prograding Carbonate Platform Margin, Great Bahama Bank: Results of the Bahama Drilling Project. SEPM Special Publication, pp. 101-134.

Meckler, A.N., Ziegler, M., Millan, M.I., Breitenbach, S.F.M., Bernasconi, S.M., 2014. Longterm performance of the Kiel carbonate device with a new correction scheme for clumped isotope measurements. Rapid Communication Mass Spectrometry 28, 1705-1715.

Melim, L.A., Swart, P.K., Maliva, R.G., 2001. Meteoric and marine-burial diagenesis in the subsurface of Great Bahama Bank, in: Geology, S.f.S. (Ed.), Subsurface Geology of a Prograding Carbonate Platform Margin, Great Bahama Bank: Results of the Bahamas Drilling Projec, SEPM Special Publications, pp. 137-161.

Murray, S.T., Arienzo, M.M., Swart, P.K., 2016. Determining the $\Delta_{47}$ acid fractionation in dolomites. Geochimica et Cosmochimica Acta 174, 42-53.

Northrop, D.A., Clayton, R.N., 1966. Oxygen-isotope fractionations in systems containing dolomite. The Journal of Geology 74, 174-196.

O'Neil, J.R., Epstein, S., 1966. Oxygen isotope fractionation in the system dolomite-calcitecarbon dioxide. Science 152, 198-201.

Passey, B.H., Henkes, G.A., 2012. Carbonate clumped isotope bond reordering and geospeedometry. Earth and Planetary Science Letters 351-352, 223-236.

Pierson, B.J., 1983. Cyclic sedimentation, limestone diagenesis and dolomitization in Upper Cenozoic carbonates of the Southeastern Bahamas. Dissertation. Marine Geology and Geophysics, University of Miami. 343

Piggot, A., 2014. Microbial Influences on Sedimentation and Early Diagenesis in Carbonate Environments. Dissertation. Marine Geology and Geophysics, University of Miami.

Pinckney, J., Paerl, H.W., Bebout, B.M., 1995. Salinity control of benthic microbial mat community production in a Bahamian hypersaline lagoon. Journal of Experimental Marine Biology and Ecology 187, 223-237.

Plummer, L.N., 1975. Mixing of sea water with calcium carbonate ground wate, in: Whitten, E.H.T. (Ed.), Quantitative Studies in Geological Sciences., Geological Society of America Memoirs, pp. 219-236.

Plummer, L.N., Busenberg, E., 1982. The solubilities of calcite, aragonite and vaterite in $\mathrm{CO}_{2^{-}}$ $\mathrm{H}_{2} \mathrm{O}$ solutions between 0 and $90 \mathrm{C}$, and an evalution of the aqueous model for system $\mathrm{CaCO}_{3^{-}}$ $\mathrm{CO}_{2}-\mathrm{H}_{2} \mathrm{O}$. Geochimica et Cosmochimica Acta 46, 1011-1040. 
1018 Plummer, L.N., Vacher, H.L., MacKenzie, F.T., Bricker, O.P., Land, L.S., 1976.

1019 Hydrogeochemistry of Bermuda: A case history of ground water diagenesis of biocalcarenites.

1020 GSA Bulletin 87, 1301-1316.

1021 Purser, B.H., Tucker, M.E., Zenger, D.H., 1994. Problems, progress, and future research

1022 concerning dolomites and dolomitization, in: Purser, B.H., Tucker, M.E., Zenger, D.H. (Eds.),

1023 Dolomieu Conference on Carbonate Platforms and Dolomitization. John Wiley \& Sons, 2009,

1024 Ortisei, Italy, pp. 3-20.

1025 Saenger, C., Affek, H., Felis, T., Thiagarajan, N., Lough, J.M., Holcomb, M., 2012. Carbonate

1026 clumped isotope variability in shallow water corals: Temperature dependence and growth-related

1027 vital effects, Geochimica et Cosmochimica Acta.

1028 Saller, A.H., 1984. Petrologic and geochemical constraints on the origin of subsurface dolomite,

1029 Enewetak Atoll: An example of dolomitization by normal seawater. Geology 12, 217-220.

1030 Santrock, J., Studley, S.A., Hayes, J.M., 1985. Isotopic analyses based on the mass spectra of 1031 carbon dioxide. Analytical Chemistry 57, 1444-1448.

1032

1033

1034

1035

1036

1037

Schauer, A.J., Kelson, J., Saenger, C., Huntington, K.W., 2016. Choice of 170 correction affects clumped isotope $(\Delta 47)$ values of $\mathrm{CO} 2$ measured with mass spectrometry. Rapid Communications in Mass Spectrometry.

1038 Sharma, T., Clayton, R.N., 1965. Measurements of $\mathrm{O}^{18} / \mathrm{O}^{16}$ ratios of total oxygen of carbonates.

1039 Geochimica et Cosmochimica Acta 29, 1347-1353.

1040 Sheppard, S.M.F., Schwarcz, H.P., 1970. Fractionation of carbon and oxygen isotopes and magnesium between coexisting metamorphic calcite and dolomite. Contr. Mineral. and Petrol.

1042 26, 161-198.

1043 Shinn, E.A., Steinen, R.P., Lidz, B.H., Swart, P.K., 1989. Perspectives: Whitings a 1044 sedimentologic dilemma. journal of Sedimentary Petrology 59, 147-161.

1045 Simms, M., 1984. Dolomitization by groundwater flow systems in carbonate platforms.

1046 Transactions Gulf Coast Association Geological Society 34, 411-420.

1047 Slowey, N.C., Curry, W.B., 1995. Glacial-interglacial differences in circulation and carbon 1048 cycling within the upper western North Atlantic. Paleoceanography 10, 715-732.

1049 Steinen, R.P., Matthews, R.K., 1973. Phreatic vs. vadose diagenesis; stratigraphy and mineralogy

1050 of a cored borehole on Barbados, W. I. Journal of Sedimentary Research 43, 1012-1020. 
1051

1052

1053

1054

1055

1056

1057

1058

1059

1060

1061

1062

1063

1064

1065

1066

1067

1068

1069

1070

1071

1072

1073

1074

1075

1076

1077

1078

1079

1080

1081

1082

1083

1084

Stoessell, R.K., Ward, W.C., Ford, B.H., Schuffert, J.D., 1989. Water chemistry and CaCO3 dissolution in the saline part of an open-flow mixing zone, coastal Yucatan Peninsula, Mexico. Geological Society of America Bulletin 101, 159-169.

Supko, P.R., 1970. Depositional and diagenetic features in subsurface Bahamian rocks. Dissertation. Marine Science, University of Miami. 180

Supko, P.R., 1977. Subsurface Dolomites, San Salvador Bahamas. Journal of Sediment Petrology 47, 1063-1077.

Swart, P.K., 2000. The oxygen isotopic composition of interstitial waters: Evidence for fluid flow and recrystallization in the margin of the Great Bahama Bank, in: Swart, P.K., Eberli, G.P., Malone, M.J., Sarg, J.F. (Eds.), Proceedings of the Ocean Drilling Program, Scientific Results, pp. 91-98.

Swart, P.K., Elderfield, H., Beets, K., 2001. The ${ }^{87} \mathrm{Sr} /{ }^{86} \mathrm{Sr}$ ratios of carbonates, phosphorites, and fluids collected during the Bahamas Drilling Project cores Clino and Unda: Implications for dating and diagenesis. SEPM Special Publication 70, 175-185.

Swart, P.K., Melim, L.A., 2000. The origin of dolomites in tertiary sediments from the margin of Great Bahama Bank. Journal of Sedimentary Research 70, 738-748.

Swart, P.K., Reijmer, J., Otto, R., 2009. A reevaluation of facies on Great Bahama Bank II: Variations in the $\delta^{13} \mathrm{C}, \delta^{18} \mathrm{O}$ and mineralogy of surface sediments, Perspectives in carbonate geology: A tribute to the career of Robert Nathan Ginsburg, pp. 47-59.

Swart, P.K., Ruiz, J., Holmes, C.W., 1987. Use of strontium isotopes to constrain the timing and mode of dolomitization of upper Cenozoic sediments in a core from San Salvador, Bahamas.

Geology 5, 262-265.

Tang, J., Dietzel, M., Fernandez, A., Tripati, A.K., Rosenheim, B.E., 2014. Evaluation of kinetic effects on clumped isotope fractionation $(\Delta 47)$ during inorganic calcite precipitation Geochimica et Cosmochimica Acta.

Thiagarajan, N., Adkins, J., Eiler, J.M., 2011. Carbonate clumped isotope thermometry of deepsea corals and implications for vital effect. Geochimica et Cosmochimica Acta 75, 4416 - 4425.

Tripati, A.K., Eagle, R.A., Thiagarajan, N., Gagnon, A.C., Bauch, H., Halloran, P.R., Eiler, J.M., 2010. ${ }^{13} \mathrm{C}-{ }^{18} \mathrm{O}$ isotope signatures and 'clumped isotope' thermometry in foraminifera and coccoliths. Geochimica et Cosmochimica Acta 74, 5697-5717.

Tripati, A.K., Hill, P.S., Eagle, R.A., Mosenfelder, J.L., Tang, J., Schauble, E.A., Eiler, J.M., Zeebe, R.E., Uchikawa, J., Coplen, T.B., Ries, J.B., Henry, D., 2015. Beyond temperature: Clumped isotope signatures in dissolved inorganic carbon species and the influence of solution chemistry on carbonate mineral composition. Geochimica et Cosmochimica Acta 166, 344-371. 
Vahrenkamp, V.C., 1988. Constraints on the formation of platform dolomites: A geochemical study of late tertiary dolomite from Little Bahama Bank, Bahamas. Dissertation. Marine Geology

1087 and Geophysics, University of Miami. 434

1088 Vahrenkamp, V.C., Swart, P.K., 1990. New distribution coefficient for the incorporation of strontium into dolomite and its implications for the formation of ancient dolomites. Geology 18, $1090 \quad 387-391$.

1091 Vahrenkamp, V.C., Swart, P.K., 1994. Late Cenozoic dolomite of the Bahamas: metastable 1092 analogues for the genesis of ancient platform dolomites. Special Publications Int. Ass. Sediment 1093 21, 133-153.

1094 Vahrenkamp, V.C., Swart, P.K., Ruiz, J., 1991. Episodic dolomitization of late Cenozoic 1095 carbonates in the Bahamas: Evidence from strontium isotopes. Journal of Sedimentary Petrology 1096 61, 1002-1014.

1097 Vasconcelos, C., McKenzie, J.A., 1997. Microbial mediation of modern dolomite precipitation 1098 and diagenesis under anoxic conditions (Lagoa Vermelha, Rio de Janeiro, Brazil). Journal of 1099 Sedimentary Research 67, 378-390.

1100 Vasconcelos, C., McKenzie, J.A., Warthmann, R., Bernasconi, S.M., 2005. Calibration of the $1101 \delta^{18} \mathrm{O}$ paleothermometer for dolomite precipitated in microbial cultures and natural environmnets. 1102 Geology 33, 317-320.

1103 Wacker, U., Fiebig, J., Todter, J., Schone, B.R., Bahr, A., Friedrich, O., Tutken, T., Gischler, E., 1104 Joachimski, M.M., 2014. Empirical calibration of the clumped isotope paleothermometer using 1105 calcites of various origins. Geochimica et Cosmochimica Acta 141, 127-144.

1106 Wang, Z., Schauble, E.A., Eiler, J.M., 2004. Equilibrium thermodynamics of multiply 1107 substituted isotopologues of molecular gases. Geochimica et Cosmochimica Acta 68, 4779-4797.

1108 Ward, W.C., Halley, R.B., 1985. Dolomitization in a mixing zone of near-seawater composition, 1109 Late Pleistocene, Northeastern Uvatan Peninsula. Journal of Sedimentary Petrology 55, 407-420.

1110 Whitaker, F.F., Smart, P.L., 1990. Active circulation of saline ground waters in carbonate 1111 platforms: Evidence from the Great Bahama Bank. Geology 18, 200-203.

1112 Whitaker, F.F., Smart, P.L., 1993. Circulation of saline ground water in carbonate platforms - A 1113 review and case study from the Bahamas, in: Horbury, A.D., Robinson, A.G. (Eds.), Studies in 1114 Geology 36: Diagenesis and Basin Development, pp. 113-134.

1115 Williams, S.C., 1985. Stratigraphy, facies evolution, and diagenesis of late cenozoic limestones 1116 and dolomites, Little Bahama Bank, Bahamas. Dissertation. Marine Geology and Geophysics, 1117 University of Miami. 461

1118 Winkelstern, I.Z., Kaczmarek, S.E., Lohmann, K.C., Humphrey, J.D., 2016. Calibration of 1119 dolomite clumped isotope thermometry. Chemical Geology. 
1120 Winkelstern, I.Z., Lohmann, K.C., 2016. Shallow burial alteration of dolomite and limestone 1121 clumped isotope geochemistry. Geology.

1122 Zaarur, S., Affek, H.P., Brandon, M.T., 2013. A revised calibration of the clumped isotope 1123 thermometer. Earth and Planetary Science Letters 382, 47-57.

1124 Zheng, Y.-F., 1999. Oxygen isotope fractionation in carbonate and sulfate minerals.

1125 Geochemical Journal 33, 109-126.

1126

1127

1128 


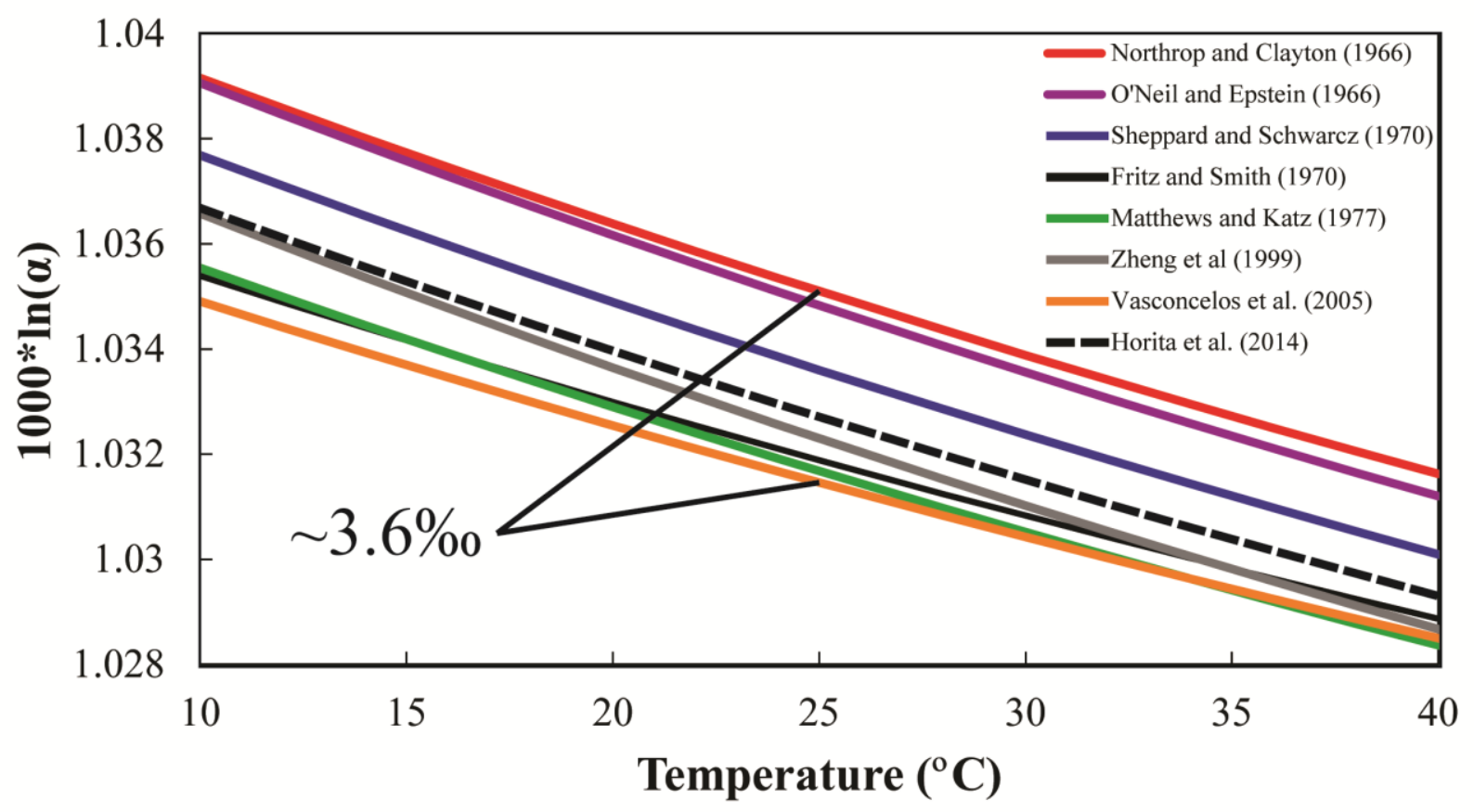

1129

1130 


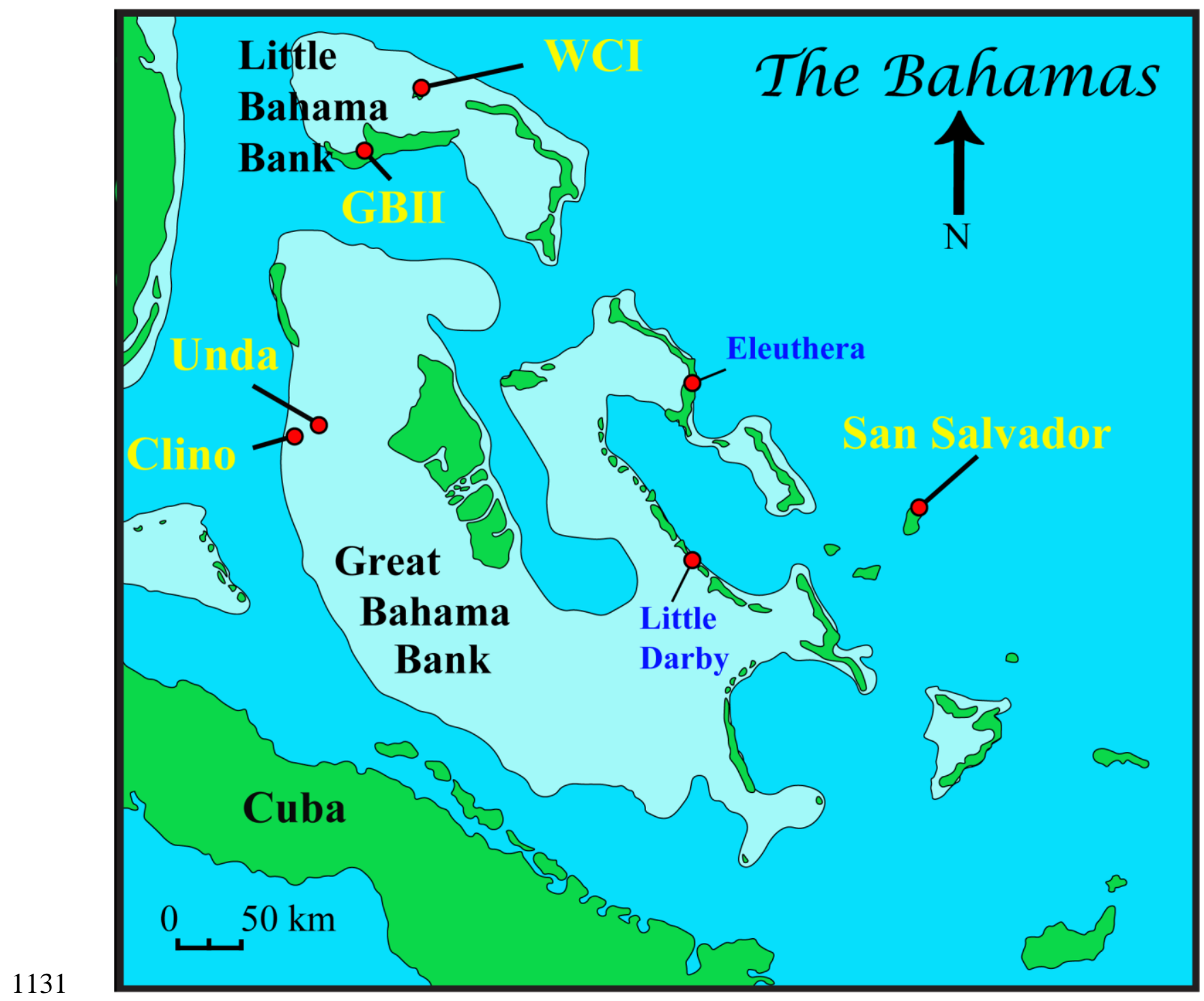

1132 
A)

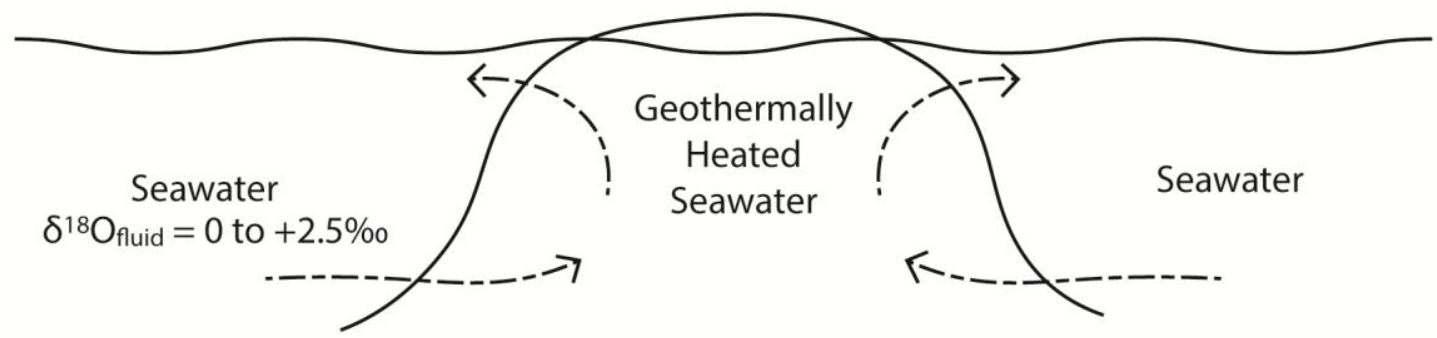

B)

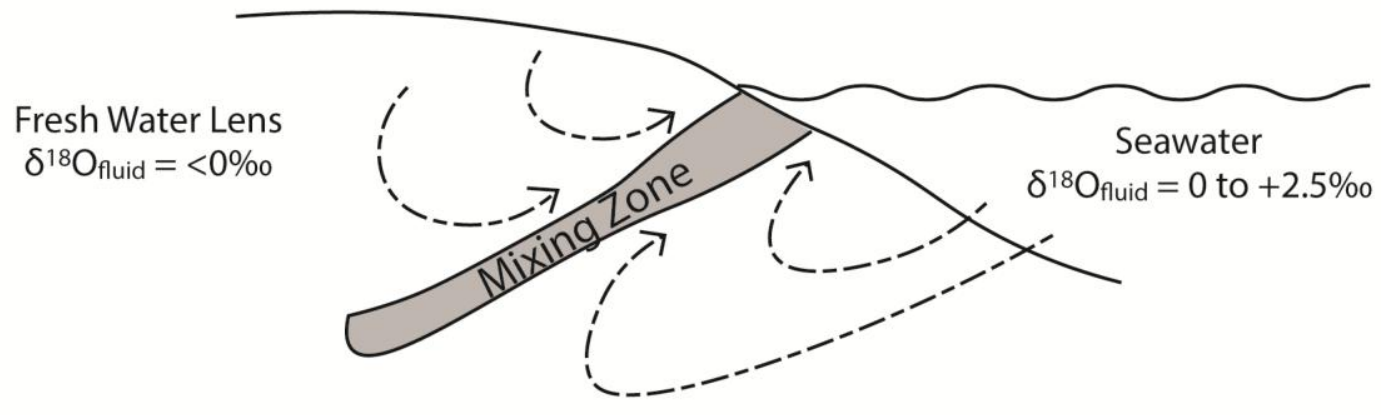

C)

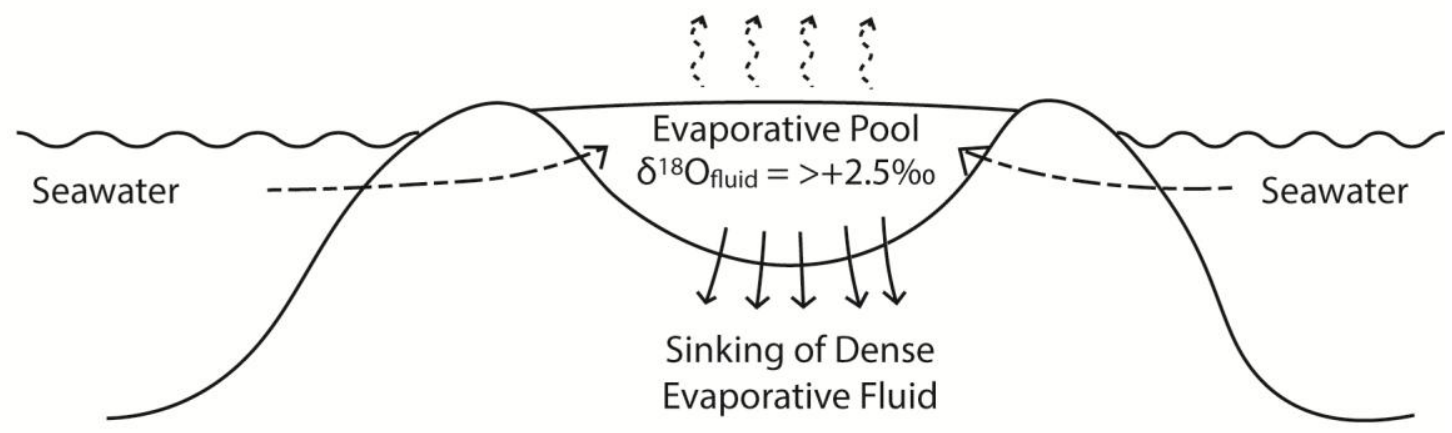

1133

1134 

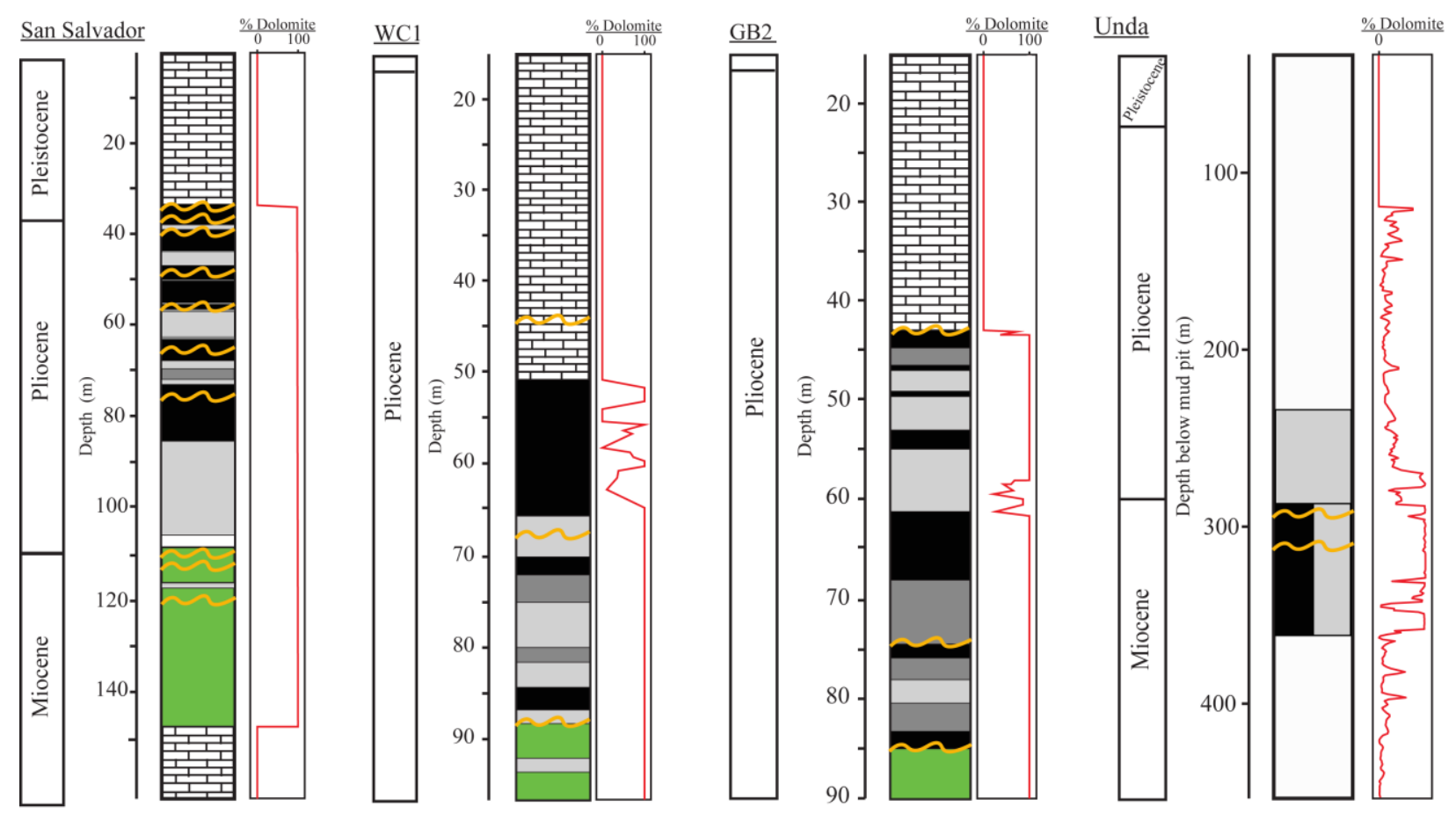

\section{5}

Carbonate Texture 


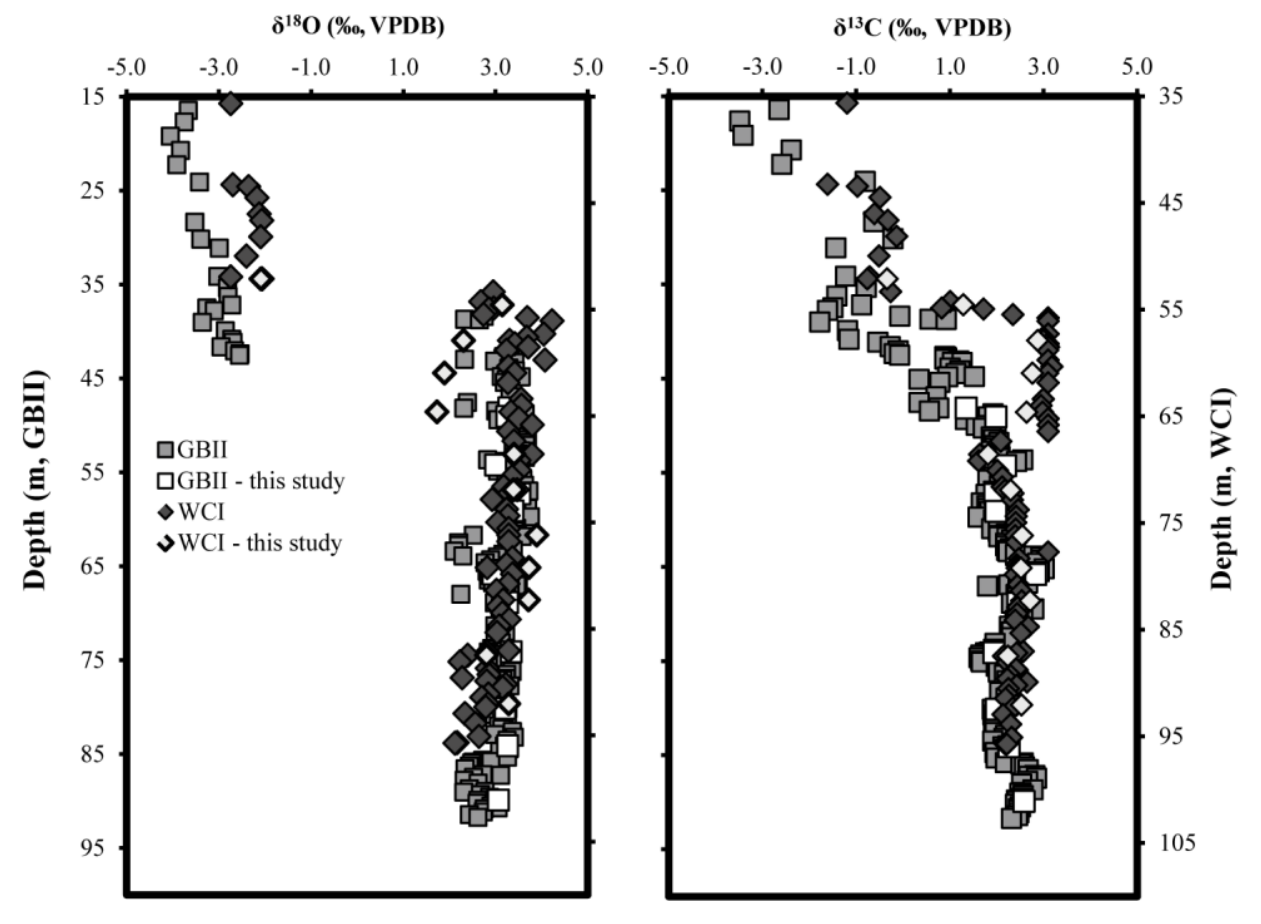



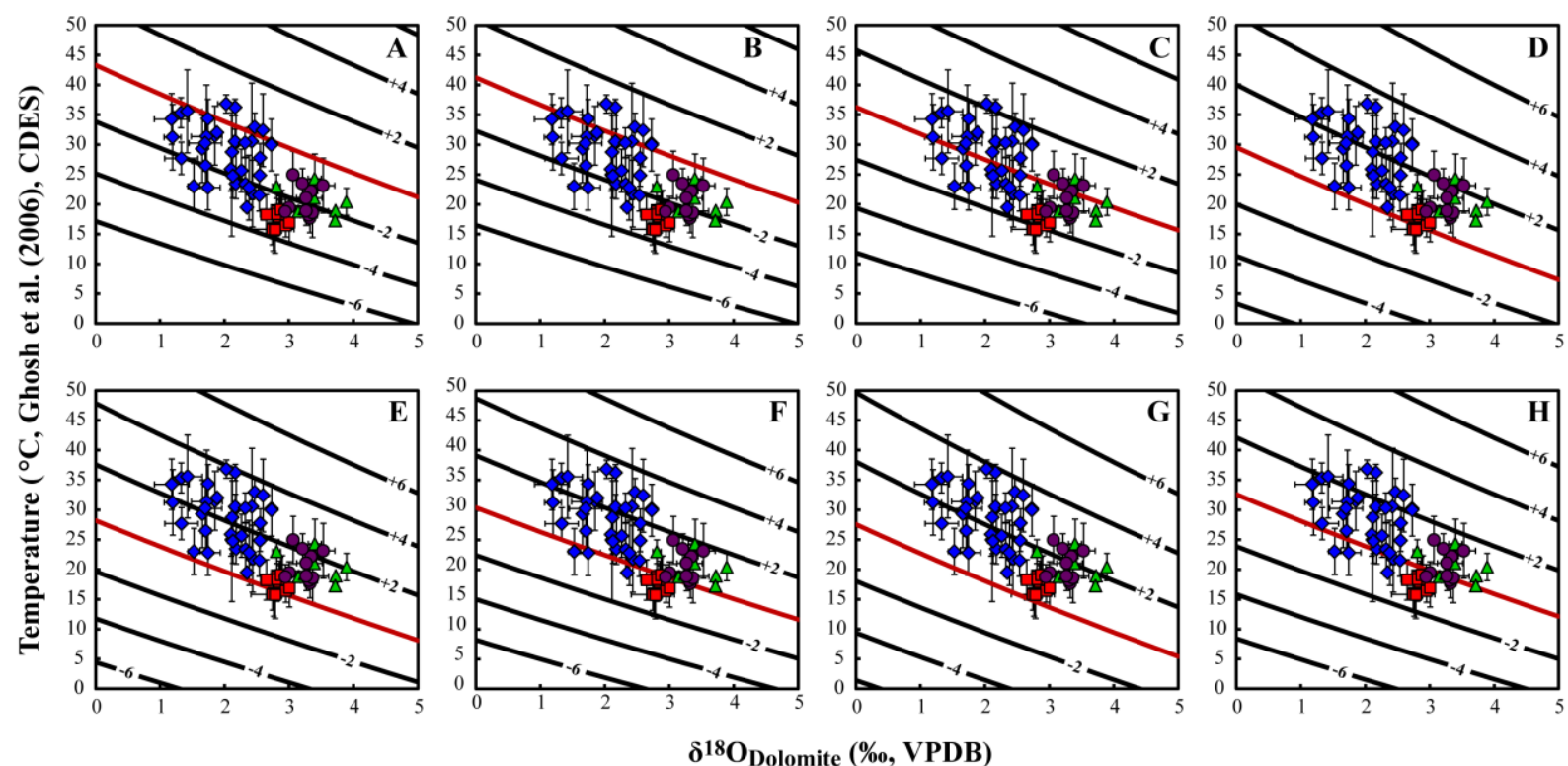

Legend

1139

$\checkmark$ San Salvador $\square$ Unda $\bigcirc$ GB2 $\triangle$ WC1 $\longrightarrow \delta^{18}$ Ofluid $=0 \%$ (VSMOW) 

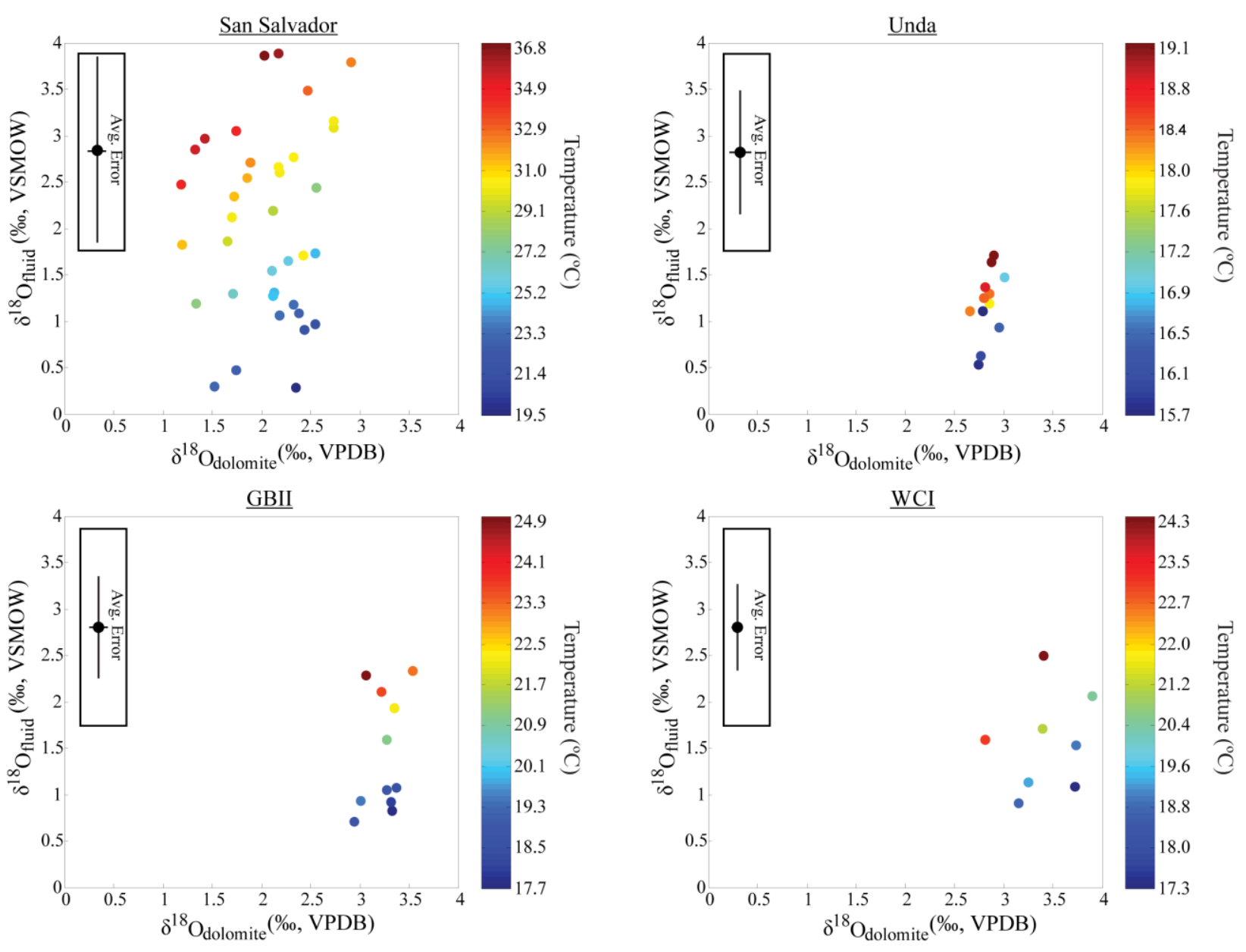


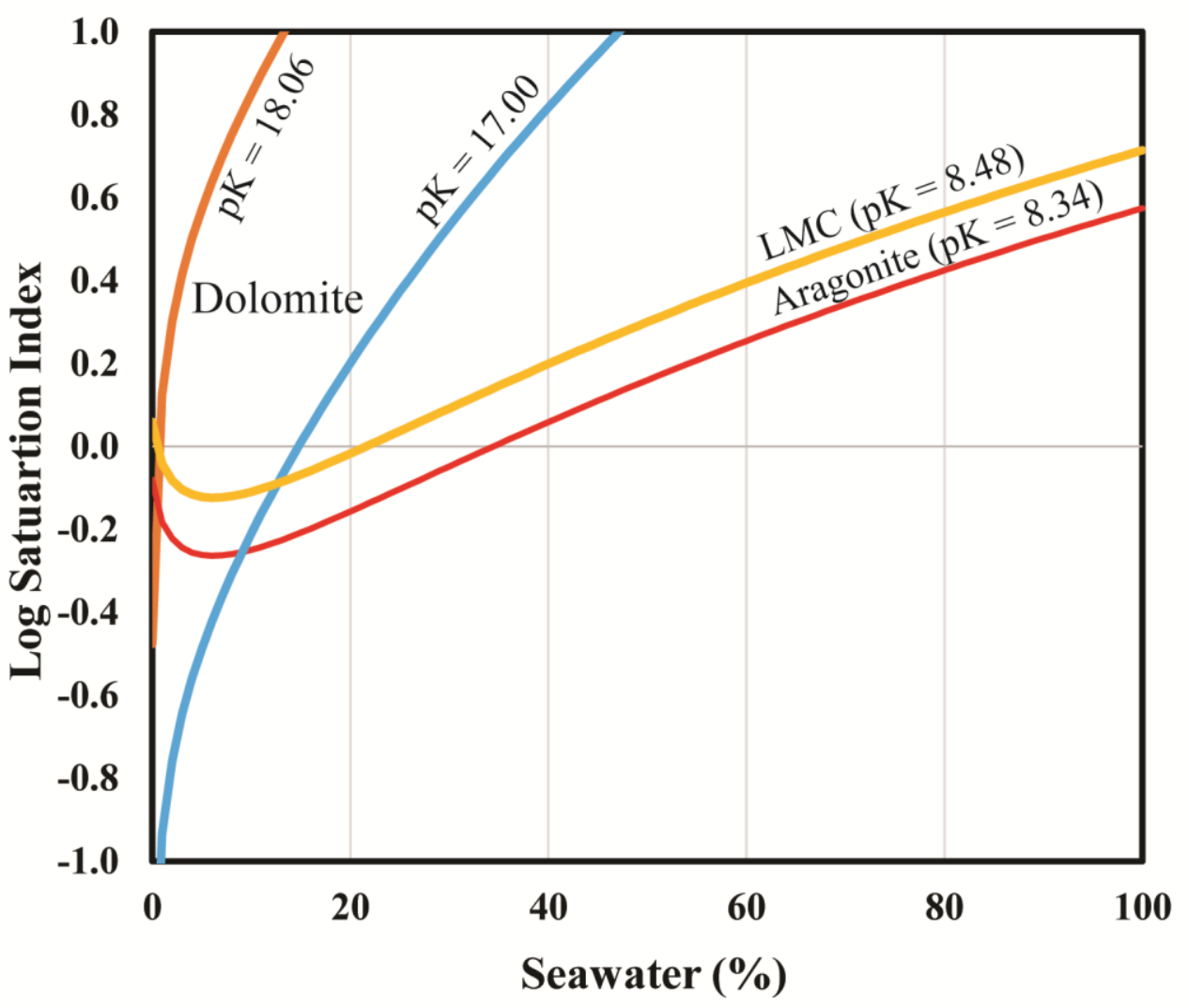

1143

1144 

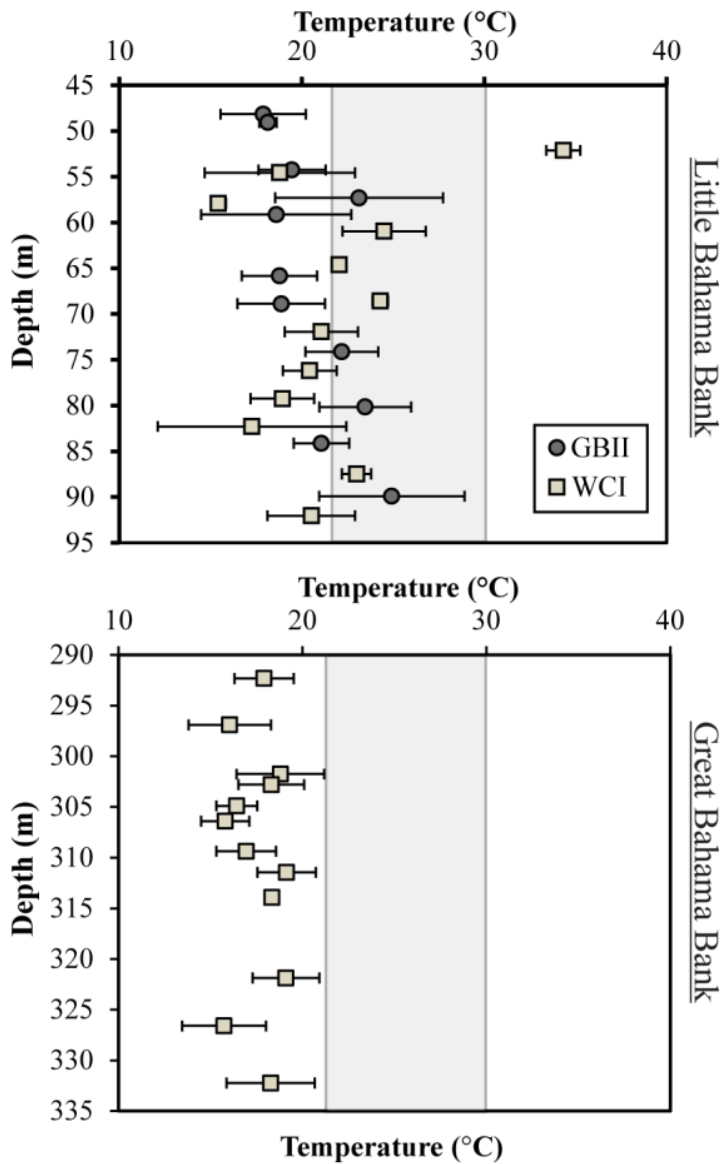

1145

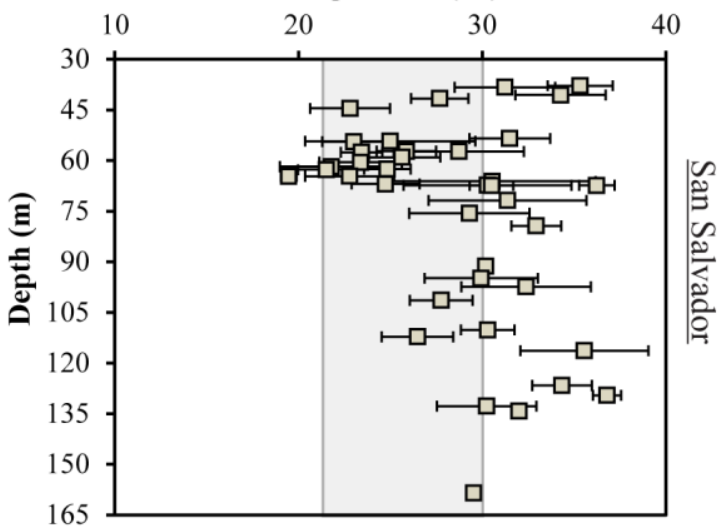

1146 


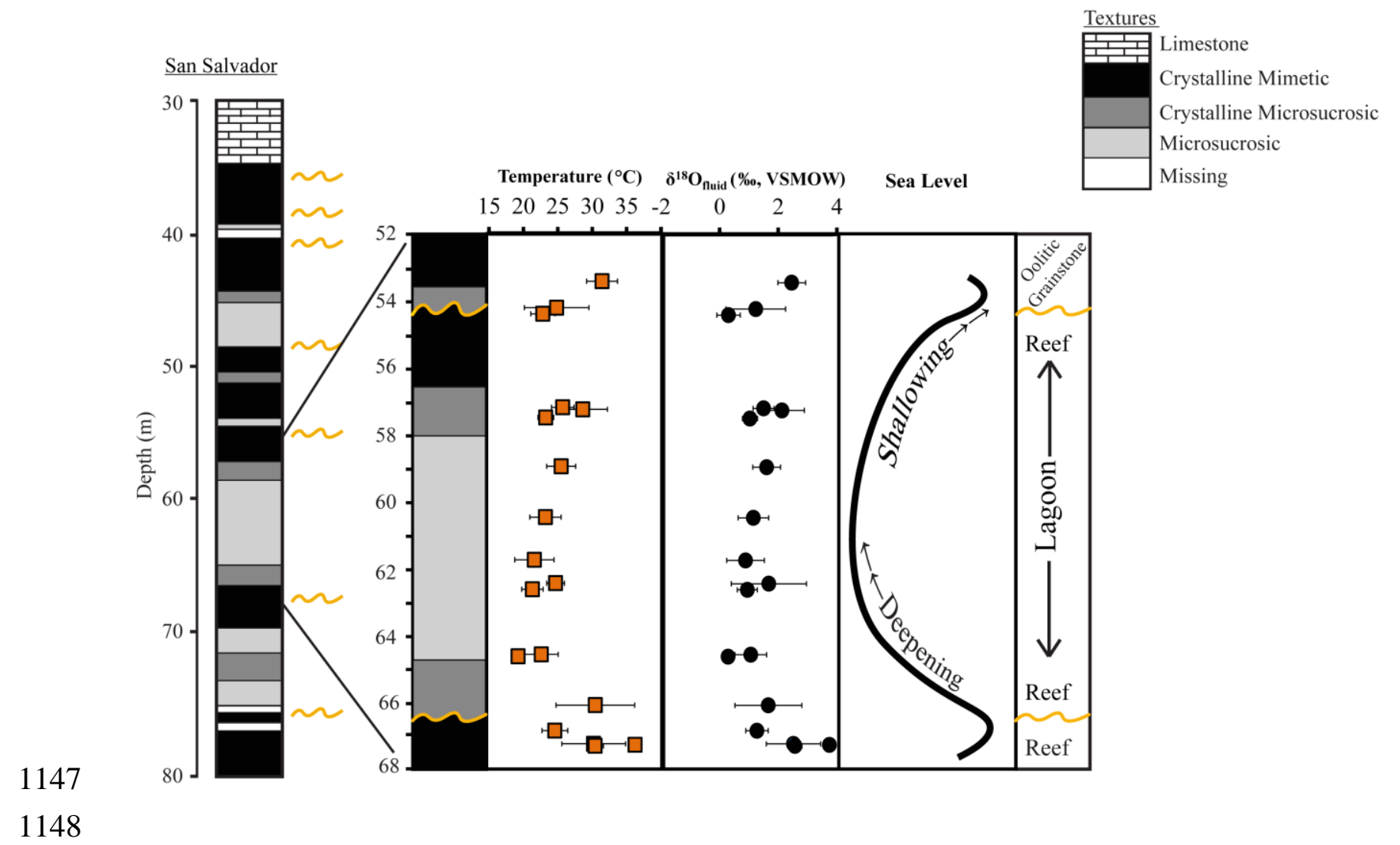




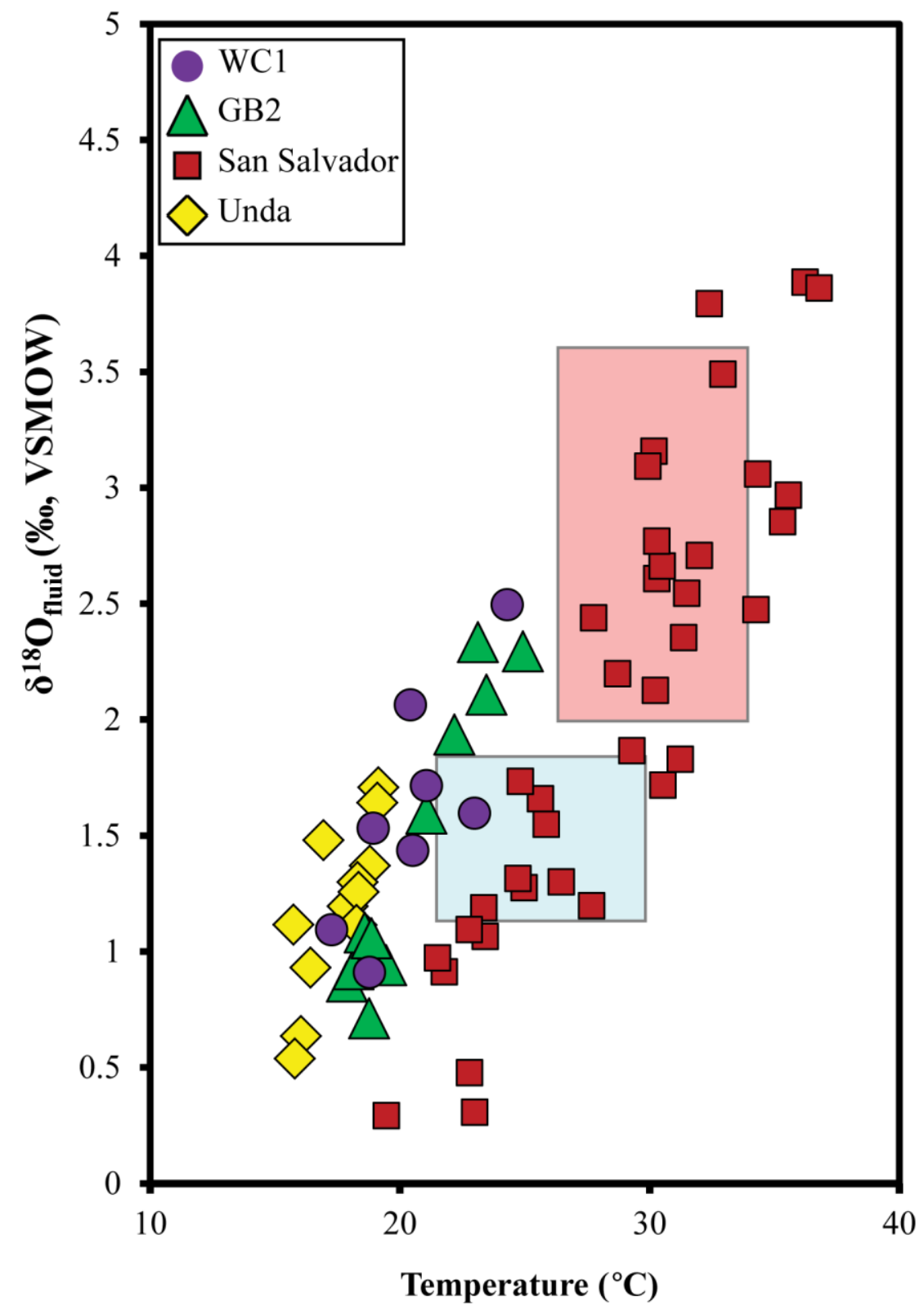

1149 
Table 1 - Summary of Bahamian core clumped isotope analysis

\begin{tabular}{ccccccc}
\hline $\begin{array}{c}\text { Depth } \\
(\mathrm{m})\end{array}$ & $(\mathrm{n})$ & $\begin{array}{c}\delta^{13} \mathrm{C}_{\text {carbonate }} \\
(\%), \text { VPDB }\end{array}$ & $\begin{array}{c}\delta^{18} \mathrm{O}_{\text {carbonate }} \\
(\%), \text { VPDB }\end{array}$ & $\begin{array}{c}\Delta_{47} \\
(\%)\end{array}$ & $\begin{array}{c}\text { Temp. } \\
\left({ }^{\circ} \mathrm{C}\right)\end{array}$ & $\begin{array}{c}\delta^{18} \mathrm{O}_{\text {fluid }} \\
(\%)\end{array}$ \\
\hline$W C I$ & & & & & & \\
52.12 & 2 & $-0.34 \pm 0.01$ & $-2.09 \pm 0.01$ & $0.668 \pm 0.004$ & $34 \pm 1$ & $2.2 \pm 0.2$ \\
54.56 & 2 & $1.29 \pm 0.00$ & $3.15 \pm 0.10$ & $0.742 \pm 0.021$ & $19 \pm 4$ & $0.9 \pm 0.9$ \\
57.91 & 2 & $2.88 \pm 0.06$ & $2.31 \pm 0.12$ & $0.759 \pm 0.002$ & $15 \pm 1$ & $-0.4 \pm 0.2$ \\
60.96 & 2 & $2.76 \pm 0.02$ & $1.90 \pm 0.01$ & $0.713 \pm 0.011$ & $25 \pm 2$ & $2.0 \pm 0.5$ \\
64.62 & 1 & 2.6 & 1.7 & 0.749 & 22 & 1.2 \\
68.58 & 2 & $1.82 \pm 0.01$ & $3.40 \pm 0.03$ & $0.714 \pm 0.002$ & $24 \pm 1$ & $2.5 \pm 0.1$ \\
71.93 & 2 & $2.30 \pm 0.01$ & $3.39 \pm 0.06$ & $0.730 \pm 0.010$ & $21 \pm 2$ & $1.7 \pm 0.4$ \\
76.20 & 2 & $2.55 \pm 0.02$ & $3.89 \pm 0.03$ & $0.733 \pm 0.007$ & $20 \pm 1$ & $2.1 \pm 0.3$ \\
79.25 & 2 & $2.52 \pm 0.01$ & $3.73 \pm 0.02$ & $0.741 \pm 0.009$ & $19 \pm 2$ & $1.5 \pm 0.5$ \\
82.30 & 2 & $2.72 \pm 0.03$ & $3.72 \pm 0.12$ & $0.750 \pm 0.027$ & $17 \pm 5$ & $1.1 \pm 1.1$ \\
87.48 & 2 & $2.24 \pm 0.01$ & $2.81 \pm 0.06$ & $0.720 \pm 0.003$ & $23 \pm 1$ & $1.6 \pm 0.2$ \\
92.05 & 2 & $2.53 \pm 0.04$ & $3.24 \pm 0.06$ & $0.733 \pm 0.003$ & $20 \pm 6$ & $1.1 \pm 0.1$
\end{tabular}

GBII

$\begin{array}{lllllll}48.16 & 3 & 1.35 \pm 0.01 & 3.33 \pm 0.08 & 0.747 \pm 0.013 & 17 \pm 2 & 0.8 \pm 0.6 \\ 49.07 & 2 & 1.99 \pm 0.08 & 3.31 \pm 0.13 & 0.745 \pm 0.002 & 18 \pm 1 & 0.9 \pm 0.0 \\ 54.25 & 3 & 2.19 \pm 0.04 & 3.01 \pm 0.14 & 0.738 \pm 0.009 & 19 \pm 2 & 0.9 \pm 0.5 \\ 57.30 & 3 & 1.96 \pm 0.08 & 3.53 \pm 0.18 & 0.720 \pm 0.022 & 23 \pm 4 & 2.3 \pm 0.9 \\ 59.13 & 2 & 1.99 \pm 0.09 & 3.37 \pm 0.01 & 0.743 \pm 0.021 & 19 \pm 4 & 1.1 \pm 1.0 \\ 65.84 & 3 & 2.84 \pm 0.04 & 2.94 \pm 0.06 & 0.742 \pm 0.021 & 19 \pm 2 & 0.7 \pm 0.5 \\ 68.88 & 3 & 2.46 \pm 0.13 & 3.27 \pm 0.35 & 0.741 \pm 0.012 & 19 \pm 2 & 1.1 \pm 0.5 \\ 74.13 & 3 & 1.95 \pm 0.03 & 3.34 \pm 0.10 & 0.725 \pm 0.009 & 22 \pm 2 & 1.9 \pm 0.4 \\ 80.16 & 3 & 2.00 \pm 0.02 & 3.21 \pm 0.07 & 0.718 \pm 0.012 & 23 \pm 3 & 2.1 \pm 0.6 \\ 84.12 & 3 & 2.27 \pm 0.07 & 3.27 \pm 0.15 & 0.730 \pm 0.008 & 21 \pm 2 & 1.6 \pm 0.5 \\ 89.92 & 3 & 2.59 \pm 0.03 & 3.07 \pm 0.03 & 0.711 \pm 0.019 & 25 \pm 4 & 2.3 \pm 0.9\end{array}$

$\begin{array}{cllllll}\text { Unda } & & & & & \\ 292.33 & 3 & 2.23 \pm 0.03 & 2.85 \pm 0.09 & 0.746 \pm 0.015 & 18 \pm 3 & 1.2 \pm 0.8 \\ 296.90 & 3 & 2.80 \pm 0.05 & 2.76 \pm 0.10 & 0.756 \pm 0.021 & 16 \pm 4 & 0.6 \pm 1.0 \\ 301.75 & 3 & 2.66 \pm 0.07 & 2.81 \pm 0.18 & 0.742 \pm 0.021 & 19 \pm 4 & 1.4 \pm 1.2 \\ 302.79 & 3 & 2.82 \pm 0.06 & 2.85 \pm 0.13 & 0.744 \pm 0.016 & 18 \pm 3 & 1.3 \pm 0.9 \\ 304.90 & 3 & 2.62 \pm 0.01 & 2.95 \pm 0.08 & 0.754 \pm 0.010 & 16 \pm 2 & 0.9 \pm 0.5 \\ 306.40 & 4 & 2.44 \pm 0.13 & 2.74 \pm 0.33 & 0.757 \pm 0.014 & 16 \pm 3 & 0.5 \pm 0.7 \\ 309.37 & 4 & 2.52 \pm 0.04 & 3.01 \pm 0.07 & 0.751 \pm 0.017 & 17 \pm 3 & 1.5 \pm 0.5 \\ 311.45 & 4 & 2.44 \pm 0.13 & 2.90 \pm 0.13 & 0.740 \pm 0.016 & 19 \pm 3 & 1.7 \pm 0.8 \\ 313.94 & 2 & 2.80 \pm 0.03 & 2.79 \pm 0.17 & 0.744 \pm 0.001 & 18 \pm 1 & 1.3 \pm 0.2 \\ 321.87 & 3 & 2.77 \pm 0.03 & 2.87 \pm 0.05 & 0.740 \pm 0.016 & 19 \pm 3 & 1.6 \pm 1.0 \\ 326.59 & 3 & 2.92 \pm 0.02 & 2.79 \pm 0.08 & 0.758 \pm 0.021 & 16 \pm 4 & 1.1 \pm 0.1\end{array}$


Table 2 - Core Summary of Pure Dolomites

\begin{tabular}{ccccc} 
Core & $\delta^{18} \mathrm{O}_{\text {dolomite }}$ & $\delta^{13} \mathrm{C}_{\text {dolomite }}$ & $\begin{array}{c}\text { Temperature } \\
(\%), \text { VPDB }\end{array}$ & $\begin{array}{c}\delta^{18} \mathrm{O}_{\text {fluid }} \\
(\%), \text { VPDB }\end{array}$ \\
\hline ( $\left.{ }^{\circ} \mathrm{C}\right)$ & $(\%)$ \\
\hline WC1 & $2.8-3.9$ & $1.3-2.7$ & $17-24$ & $0.9-2.5$ \\
GB2 & $2.9-3.5$ & $1.4-2.8$ & $18-25$ & $0.7-2.3$ \\
San Salvador & $1.2-2.9$ & $1.5-2.9$ & $19-37$ & $0.3-3.9$ \\
Unda & $2.6-3.0$ & $2.2-3.2$ & $16-19$ & $0.5-1.7$ \\
\hline
\end{tabular}

*: Temperature is calculated from clumped isotopes using the calibration of Ghosh et al. (2006) in thr

!: The $\delta^{18} \mathrm{O}_{\text {fluid }}$ was calculate using the equation of Matthews and Katz (1977) using temperatures calc 